\title{
Revised Airlie House consensus guidelines for design and implementation of ALS clinical trials
}

Leonard H. van den Berg, MD, PhD, Eric Sorenson, MD, Gary Gronseth, MD, Eric A. Macklin, PhD, Jinsy Andrews, MD, Robert H. Baloh, MD, PhD, Michael Benatar, MD, PhD, James D. Berry, MD, Adriano Chio, MD, Philippe Corcia, MD, PhD, Angela Genge, MD, Amelie K. Gubitz, PhD, Catherine Lomen-Hoerth, MD, PhD, Christopher J. McDermott, MD, Erik P. Pioro, MD, PhD, Jeffrey Rosenfeld, MD, PhD, Vincenzo Silani, MD, Martin R. Turner, MBBS, PhD, Markus Weber, MD, Benjamin Rix Brooks, MD, Robert G. Miller, MD, and Hiroshi Mitsumoto, MD, DSc, for the Airlie House ALS Clinical Trials Guidelines Group

Neurology ${ }^{\circledR}$ 2019;92:e1610-e1623. doi:10.1212/WNL.0000000000007242

\section{Abstract}

\section{Objective}

To revise the 1999 Airlie House consensus guidelines for the design and implementation of preclinical therapeutic studies and clinical trials in amyotrophic lateral sclerosis (ALS).

\section{Methods}

A consensus committee comprising 140 key members of the international ALS community (ALS researchers, clinicians, patient representatives, research funding representatives, industry, and regulatory agencies) addressed 9 areas of need within ALS research: (1) preclinical studies; (2) biological and phenotypic heterogeneity; (3) outcome measures; (4) disease-modifying and symptomatic interventions; (5) recruitment and retention; (6) biomarkers; (7) clinical trial phases; (8) beyond traditional trial designs; and (9) statistical considerations. Assigned to 1 of 8 sections, committee members generated a draft set of guidelines based on a "background" of developing a (pre)clinical question and a "rationale" outlining the evidence and expert opinion. Following a 2-day, face-to-face workshop at the Airlie House Conference Center, a modified Delphi process was used to develop draft consensus research guidelines, which were subsequently reviewed and modified based on comments from the public. Statistical experts drafted a separate document of statistical considerations (section 9).

\section{Results}

In this report, we summarize 112 guidelines and their associated backgrounds and rationales. The full list of guidelines, the statistical considerations, and a glossary of terms can be found in data available from Dryad (appendices e-3-e-5, doi.org/10.5061/dryad.32q9q5d). The authors prioritized 15 guidelines with the greatest potential to improve ALS clinical research.

\section{Conclusion}

The revised Airlie House ALS Clinical Trials Consensus Guidelines should serve to improve clinical trial design and accelerate the development of effective treatments for patients with ALS.

\author{
Correspondence \\ Dr. van den Berg \\ L.H.vandenBerg@ \\ umcutrecht.nl
}




\section{Glossary}

ALS = amyotrophic lateral sclerosis; NIV = noninvasive ventilation; PALS = people living with amyotrophic lateral sclerosis; $\mathrm{QOL}=$ quality of life.

Consensus guidelines for performing clinical trials in amyotrophic lateral sclerosis (ALS) were published in 1999, only a few years after approval of riluzole, the first drug to treat ALS. ${ }^{1}$ Since then, more than 40 clinical trials have provided clinical trial experience, and 2 additional drugs have been approved: dextromethorphan/quinidine for symptomatic treatment of pseudobulbar affect and the disease-modifying drug edaravone. ${ }^{2,3}$ Riluzole provides a modest prolongation of survival and edaravone a modest slowing of functional decline in a selected cohort, but there is still an urgent need for more effective therapies.

The following advances have raised expectations and may improve ALS trial success: (1) the ability to model human disease using induced pluripotent stem cell lines ${ }^{4,5} ;(2)$ the discovery of an increasing number of ALS-associated genes ${ }^{6}$; (3) recognition of ALS as a phenotypically, etiologically, and biologically heterogeneous disease ${ }^{6,7}$; (4) the development of techniques to analyze "big data" to subclassify ALS more accurately and generate personalized prediction models ${ }^{8,9}$; and (5) the emergence of new outcome measures such as disease staging and technology-assisted outcomes. ${ }^{10,11}$ In addition, rigorous methods of establishing trial guidelines have evolved. The modified Delphi process has become a common method of achieving consensus, particularly when scientific evidence is suboptimal. ${ }^{12}$

In 2016, international stakeholders met at the Airlie House Conference Center, Warrenton, VA, to develop new ALS clinical trials research guidelines using the modified Delphi method.

\section{Methods}

Following the proposal to revise the 1999 guidelines at the ALS Research Group Summit Meeting, held October 2014, an Organizing Committee and Advisory Board were assembled including international stakeholders in ALS research. The Organizing Committee identified 9 areas to be addressed: (1) preclinical studies; (2) biological and phenotypic heterogeneity; (3) outcome measures; (4) therapeutic and symptomatic interventions; (5) recruitment and retention; (6) biomarkers; (7) clinical trial phases; (8) beyond traditional trial designs; and (9) statistical considerations (see appendix 1 for the leadership and appendix 2 for membership of each section).

The first stage of developing the guidelines involved identifying key members of the international ALS community, including researchers, clinicians, health care professionals, patients and caregivers, representatives from patient advocacy groups, industry, funding agencies, and regulatory agencies. Each member was assigned to 1 of the 8 nonstatistical sections with a maximum of 20 people/section. Seven experts in statistics produced a separate document on Statistical Considerations. These individuals also participated in 1 or 2 of the nonstatistical sections. Under the guidance of the section leaders, the nonstatistical sections independently identified key areas to be addressed within their topic. This resulted in a draft document including a background describing the context for each topic, a series of preliminary evidence-informed guidelines, and a rationale providing the evidence and expert opinion supporting each guideline. Each statement within the rationale was classified as one of the following: (1) supported by evidence (with appropriate references); (2) accepted on principle (if the statement is widely believed to be true by the ALS community even in the absence of conclusive evidence); or (3) an inference logically derived from other premises (deductive conclusion).

The second stage of developing guidelines was a face-to-face meeting of stakeholders that took place in the Airlie House Conference Center in Warrenton, VA, in March 2016. Appointed leaders from each group presented the draft guidelines, which was followed by a discussion by all conference participants. Discussions focused on the logical rationale for the guidelines, validity of the axiomatic and evidence statements, logical basis of any inferences, and the absence of any necessary premises. Following the discussion, additional comments on each of the guidelines were submitted anonymously. Each section met again independently to review the feedback and provide modifications to their document's background, rationale, or guidelines. This resulted in a second draft document from each of the 8 sections.

The third stage of developing guidelines included a monthlong public comment period (August 2016) on the 8 nonstatistical documents. Each section met to review the publicly provided anonymous feedback, modify content as needed, and provide a written explanation for actions taken or not taken to modify the document in response to the feedback. This resulted in a third draft document from each of the sections (data available from Dryad, appendix e-4, doi.org/10. 5061/dryad.32q9q5d).

The fourth stage of developing the guidelines entailed a modified Delphi consensus process in which the guidelines and supporting rationales were reviewed under the guidance of G.G. (American Academy of Neurology, Guideline Methodologist). ${ }^{12}$ During this stage, the members of each 
section provided anonymous judgments regarding the cogency of the rationales supporting the guidelines and the anticipated impact of each guideline. Cogency issues were addressed by answering the following yes/no questions:

1. Assuming all premises are true, is the rationale logical?

2. Are the evidence-based statements correct?

3. Do you agree with the stipulated axioms?

4. Are the internal inferences correct?

5. Are important premises missing from the rationale?

If all 5 questions gained an affirmative response from $80 \%$ or more of the respondents, consensus was declared.

Next, the respondents were asked to assess, using a 4-point ordinal score, how adherence to the guidelines would affect the following domains:

1. The benefit relative to harm ratio (large, moderate, small, none)

2. Feasibility (always, usually, occasionally, rarely)

3. Cost relative to benefit (small, moderate, large, very large)

Consensus on the guidelines was declared when $80 \%$ of respondents rated the effect of adherence within 1 ordinal rank in all 3 domains. If consensus was not achieved after the first round of voting, guidelines were reviewed, modified, and subjected to subsequent rounds of voting, up to a maximum of 3. After consensus was attained, a guideline was rejected if the lowest modal score in any domain indicated the lowest level of effect (no benefit, rarely feasible, very large cost). Otherwise, the strength of the guideline was indicated by the auxiliary verbs may, should, or must. Guidelines were designated by "may" when the lowest modal score in any domain was in the second lowest category (small benefit, occasionally feasible, large cost) and indicated reasonable options for ALS researchers. Guidelines designated by "should" resulted when the lowest modal score in any domain was in the second highest category (moderate benefit, usually feasible, moderate cost) and indicated actions ALS researchers would usually follow. Guidelines were designated by "must" when modal scores in all domains were in the highest category (large benefit, always feasible, small cost) and indicated actions would almost always follow.

This process generated a final list of 112 guidelines. Because of the large number of guidelines generated, the section leaders and conference organizers were asked to prioritize 15 guidelines with the greatest potential to improve ALS clinical research. These high-priority guidelines are summarized in the results section below. Section 9 on statistical guidelines was not developed using the modified Delphi process.

We emphasize that these are guidelines that were not developed using the American Academy of Neurology's practice guideline development process.

\section{Results}

For a full review of the ALS Clinical Trials Guidelines, the reader is referred to data available from Dryad (appendices e-4 and e-5, doi.org/10.5061/dryad.32q9q5d). A summary of the most important guidelines and those prioritized (marked with ${ }^{*}$ ) by section leaders and conference organizers are presented below.

\section{Preclinical studies}

\section{Background}

Demonstrations of efficacy in animal models have not led to successful therapies in humans. The development of drugs has been hampered by genetically engineered animal models that do not reflect the complete spectrum of phenotypes present in people living with ALS (PALS) and by inconsistency in the design and execution of preclinical studies, as well as a paucity of naturally occurring ALS animal models. ${ }^{13-16}$

Our ability to model human disease using induced pluripotent stem cell lines, 3-dimensional tissue models, and other complex in vitro systems, has improved dramatically. ${ }^{4,5}$ Such cellular model systems permit confirmation of target engagement but may not effectively model the complex pathophysiology of ALS.

\section{Guidelines}

- $\quad$ *Investigators should provide a firm biological rationale for moving a therapeutic candidate into human trials. This rationale may arise from data obtained in engineered animal models or cellular models, naturally occurring ALS-like animal diseases, and/or from human clinical data.

- Investigators should use preclinical models for assessment of (1) efficacy (ALS models) or (2) safety, toxicity, bioavailability, and biodistribution (can also be conducted in wild-type animals/cells).

- Investigators may prioritize development of model systems that recapitulate key pathologies seen in sporadic ALS, such as cytoplasmic TDP-43 (TAR DNA-binding protein 43) mislocalization.

- To enhance existing in vitro models, investigators may develop model systems with multiple relevant cell types in organoid-like or similar 3-dimensional structures to improve cellular maturity and to study noncell autonomous disease processes.

- *Investigators should develop preclinical pharmacodynamic and target engagement biomarkers for therapeutic candidates to inform the design of human trials whenever possible.

- Investigators should develop, publish, and adhere to best practice guidelines for the use of fully characterized preclinical ALS models.

- * *nvestigators and research funders should commit effort, time, and funds to independent preclinical validation studies of therapeutic candidates, and publish positive 
and negative results, ideally in a peer-reviewed, openaccess format.

\section{Biological and phenotypic heterogeneity}

\section{Background}

Incident cases (all new cases diagnosed within a specific time frame [usually 6 months to a year after diagnosis]) have a worse prognosis than prevalent cases (all existing diagnosed cases). Prevalent cases are generally younger and more likely to have a spinal presentation and slower progression. ${ }^{17-19}$

While the clinical presentation of familial cases resembles that of sporadic cases, specific gene abnormalities may influence the clinical phenotype and prognosis. Genetic analyses could be performed before and during trials in cases of unexpected response since little is known regarding the genetic-epigenetic interplay or modifier gene polymorphisms in ALS.

More than $30 \%$ of PALS manifest cognitive impairment, which may exacerbate functional decline and lead to earlier death. ${ }^{20}$ There are multiple other factors that affect phenotype and survival, but stratification can realistically be performed for only 3 or 4 factors, depending on the size of the trial. The issue of having to stratify for too many variables could be overcome by the use of a reliable prediction model of prognosis. ${ }^{9}$

\section{Guidelines}

- Investigators should preferentially enroll PALS with "clinically definite," "clinically probable," "probablelaboratory supported," and "clinically possible" ALS, who have a short interval from disease onset to trial entry.

- Investigators should stratify for genetic factors and cognitive (especially executive function) and behavioral impairments.

- *Investigators should collect DNA from all participants, when possible, to allow genetic post hoc analyses, which may reveal important stratification or screening factors for a subsequent clinical trial(s).

- Investigators should choose to stratify for factors most relevant to the outcome measure of the trial.

- Investigators could stratify based on prognostic systems or prediction models.

\section{Outcome measures}

\section{Background}

For a primary outcome, an endpoint is needed in phase 3 clinical trials that is robust, can be reliably measured, and is clinically meaningful. Survival and functional scales fulfill these criteria but have limitations: survival trials require large numbers of patients with long follow-up time, while functional scales are limited because of deaths and variable follow-up periods with resulting missing data points. ${ }^{21-23}$ Other or additional outcome measures will have to be included, explored, or validated. A short background of each of these (potential) outcome measures is below.

An endpoint combining survival and function may adjust for dropouts and increase power. ${ }^{24,25}$
Muscle strength: As progressive weakness is the cardinal symptom of ALS, accurate measurement of muscle strength represents a direct measure of disease status. ${ }^{24-26}$

Respiratory failure carries a poor prognosis and is the most common cause of death in ALS.

Quality of life (QOL) is an important part of human existence and a critical outcome of treatment for PALS. ${ }^{27,28}$

Cognitive and behavioral abnormalities have been recognized in many patients with ALS and can be debilitating. ${ }^{29}$

Motor neuron function: Electrophysiology can assess the function of the upper and lower motor neurons.

Staging: Various methods of clinically staging ALS have been proposed. ${ }^{10,30-32}$

Responder analyses: With our improved understanding of ALS as a multifactorial disorder, responder analyses have the potential to demonstrate beneficial effects of a proposed treatment on a subset of PALS with a shared unique pathophysiology. Such benefits may be missed in a broader analysis that pools all PALS.

Technology-assisted outcomes of mobility through use of pedometers, accelerometers, activity trackers, and motion analysis systems could be used to more objectively quantify daily locomotor activities.

Networks (NEALS [Northeast ALS Consortium], TRICALS [Trial Research Initiative to Cure ALS]) have been established to organize adequate training and certification to ensure quality control of outcome measures.

\section{Guidelines}

- Investigators should include either a survival analysis or functional assessment as the primary outcome measure in phase 3 trials with the alternative included as a secondary outcome.

- Investigators may include a combined survival/functional outcome measure as an exploratory endpoint.

- Investigators may include quantitative strength assessments as a primary outcome measure.

- Investigators may include a health-independent, ALSspecific QOL scale as a primary outcome measure in symptomatic management trials.

- Investigators may include assessments of cognitive or behavioral function as primary or secondary outcome measures.

- Investigators should use measures of pulmonary function as an outcome; these may be used as a primary outcome.

- Investigators may use electrophysiology measures, electrical impedance myography, health-independent ALSspecific QOL scales, bulbar assessment scales, staging, and caregiver measurements as secondary outcome measures. 
- Investigators may include responder analyses; the parameters and definitions of a "responder" should be specified prior to trial initiation.

- Investigators may include technology-assisted measurements as exploratory endpoints.

- *All study examiners should undergo training to ensure uniformity of study procedures across sites and across time.

\section{Disease-modifying and symptomatic interventions}

\section{Background}

Symptomatic interventions are those that do not modify the underlying pathophysiology but that treat specific symptoms. In trials of disease-modifying interventions, symptom management (e.g., with noninvasive ventilation $[\mathrm{NIV}],{ }^{33}$ nutrition, and gastrostomy ${ }^{34}$ ) may alter results obtained using validated disease scales and affect other trial outcomes including survival. Relatively few studies of symptomatic therapies or medical devices have been completed.

ALS is the result of a complex cascade involving multiple cell types and various mechanisms converging to result in motor neuron cell death. ${ }^{35}$ Thus, novel therapies could be aimed at multiple aspects of the disease cascade (i.e., multidrug trials). Combination drug therapies have proven effective for other diseases (e.g., HIV, lymphoma), even when the agents involved have not shown individual efficacy. Hence, it may not be necessary to demonstrate efficacy separately for single drugs prior to using them in multidrug ALS trials. Diseasespecific biomarkers relative to the various mechanisms being tested will be needed to assess the contribution of each drug in a multidrug trial. ${ }^{36}$

\section{Guidelines}

- *When a symptomatic intervention is effective (e.g., NIV), the investigator should consider permitting its use for trial participants. Ethical implications and challenges to enrollment should be carefully considered if such a symptomatic intervention is used as an exclusion factor for participation.

- Investigators should plan a priori analyses and standardize and record use of interventions known to affect disease course within a clinical trial (e.g., NIV, gastrostomy placement).

- *Investigators should conduct rigorous randomized controlled trials of symptomatic therapies or medical devices and utilize a patient-reported outcome and QOL measure as either a primary or secondary outcome in such trials.

- Investigators may use multidrug therapy in ALS clinical trial design.

- Trialists may use disease-specific assays for any combination drug trial to assess both clinical efficacy and the individual pathophysiologic mechanisms.

\section{Recruitment and retention}

\section{Background}

Clinical trials require the enthusiasm of PALS and caregivers to support enrollment, minimize missing data, and avoid dropout. Leading clinical trial groups from fields outside of ALS are increasingly partnering with patients and caregivers on the development of protocols, recruitment strategies, and publications. ${ }^{37,38}$

There is increasing pressure by PALS and caregivers to obtain access to treatments, including investigational therapies, which have not been adequately studied and thus, are not known to be effective. History demonstrates that most investigational therapies will ultimately be determined ineffective by well-designed clinical trials. Most therapies cause side effects, and phase 1 studies commonly underestimate the risks from new therapies because of small sample size and limited generalizability.

The Right to Try Act of 2017 was signed into law on May 30, 2018. Our full consensus-based guidelines were finalized before this time. We have added a comment on the approved legislation in the full guidelines found in data available from Dryad (appendix e-4, page 45, doi.org/10.5061/dryad.32q9q5d).

\section{Guidelines}

- $\quad{ }^{*}$ Investigators should ensure ALS clinical trial results are published in open access journals.

- All efforts should be made to improve trial design in ways that expand the number of PALS receiving the experimental therapy, including limiting use of a placebo arm.

- Investigators should explain to PALS that withdrawing from clinical trials may reduce the certainty of results.

- Because safety and efficacy of experimental drugs are not demonstrated in phase 1 clinical trials, drug developers should move as quickly as possible to subsequent phase 2 trials where more reliable data on these parameters are obtained.

- Physicians may counsel PALS requesting investigational therapies that (1) because most investigational therapies are ultimately found to be ineffective and have side effects, PALS are more likely to be harmed than helped by such treatments, (2) physicians are not obliged to prescribe such therapies outside a clinical trial designed to establish safety and efficacy, (3) insurers are unlikely to pay for such therapies, and (4) manufacturers are not obliged to make such therapies available.

\section{Biomarkers}

\section{Background}

Use of biomarkers, defined as "characteristics that are objectively measured and evaluated as indicators of normal biological processes, pathological processes, or biological responses to therapeutic interventions," may facilitate greater success of ALS clinical trials. Various types of biomarkers are recognized (table), each with a different potential application 
Table Types of biomarkers

\begin{tabular}{ll}
\hline Type of biomarker & Description \\
\hline Diagnostic & A diagnostic biomarker is a disease characteristic that categorizes a person by the presence or absence of a specific disease. \\
\hline Prognostic & A prognostic biomarker is a baseline characteristic that categorizes patients by risk of a disease or progression of a disease. \\
\hline Predictive & A predictive biomarker is a baseline characteristic that categorizes patients by their likelihood of response to a particular treatment. \\
\hline Pharmacodynamic & $\begin{array}{l}\text { A pharmacodynamic biomarker is one that demonstrates a biological response in a patient who has received a therapeutic } \\
\text { intervention. }\end{array}$ \\
\hline $\begin{array}{l}\text { Disease } \\
\text { progression }\end{array}$ & A progression biomarker is a biomarker that changes as disease advances. \\
\hline
\end{tabular}

in the clinical trial setting. In considering the potential use of biomarkers, a distinction should be made between generic biomarkers of motor neuron loss (e.g., neurofilaments) and biomarkers that might be specific to a drug with a particular mechanism of action (e.g., cytokines as markers of inflammation). A plethora of biomarker candidates (biological fluids, neuroimaging, and neurophysiologic studies) have emerged, but none have been formally validated for routine clinical or therapeutic trial use in ALS. In addition to ensuring that these candidates meet minimum methodologic criteria, pragmatic issues such as patient tolerability, burden of participation, investigator time, cost, complexity, need for specialized equipment, training, and certification will also require consideration.

\section{Guidelines}

- ${ }^{*}$ In designing and implementing ALS clinical trials, investigators should incorporate (to the extent that they have been developed and validated as such) predictive biomarkers, prognostic biomarkers, and, especially in phase 2 trials, pharmacodynamic biomarkers (table) (3 prioritized guidelines [6-1-1, 6-1-2, and 6-1-3] on pages 46 and 47 of the full guidelines found in data available from Dryad, appendix e-4, doi.org/10.5061/dryad.32q9q5d).

- *Investigators should ensure that biomarkers are quantifiable and can be measured reliably using standardized operating procedures across multiple centers, accounting for relevant sources of variability, including intra- and intersubject, intra- and interassessment (assay, evaluator, scanner), and interlaboratory/site.

- Investigators should accumulate additional experimental data to support the use of biomarkers in future clinical trials for go/no-go decisions.

\section{Clinical trial phases}

\section{Background}

The process of investigating novel treatment consists of 3 phases:

The purpose of phase 1 studies is to define the short-term safety profile, pharmacokinetic profile, and maximum tolerated dose. Many times, phase 1 trials incorporate single ascending dose and multiple ascending dose designs to accomplish these goals.
Phase 2 trials assess optimal dosing, expand pharmacokinetics, determine whether a therapy has the desired biological effect, monitor safety and tolerability, and whether a potential therapy reaches and affects its intended target. ${ }^{39,40}$ Clinical efficacy is not the main goal of phase 2 studies. ${ }^{39,41,42}$

Phase 3 trials aim to demonstrate efficacy. The long track record of negative phase 3 trials emphasizes the need for innovative trial design., ${ }^{2,39}$ Randomized, placebo-controlled clinical trials remain the most robust way to demonstrate efficacy of an intervention. ${ }^{2}$ Alternatively, there are study designs that assess efficacy without the use of placebo controls, which can be explored. ${ }^{43}$

Alternative study designs (adaptive designs, seamless phase 2/3 designs, enrichment designs, or futility designs) (see also statistical considerations in data available from Dryad, appendix e-5, doi.org/10.5061/dryad.32q9q5d) can provide an opportunity to more efficiently and rapidly conduct clinical trials to evaluate potential therapies.

There are distinct challenges and opportunities in performing early-phase gene and stem cell therapy trials in ALS, which require special approaches and unique trial designs for testing these therapies. When small subpopulations are targeted or a large effect is expected, as with certain gene therapy approaches, traditional concurrent placebo controls may not be feasible.

\section{Guidelines}

- In phase 1 studies, investigators should incorporate single ascending dose and multiple ascending dose designs to evaluate safety, pharmacokinetic profile, and maximum tolerated dose. Investigators may include a placebo control to evaluate the adverse event rate but may omit placebo when its inclusion involves excessive risk. They may choose to conduct studies in healthy volunteers or PALS depending on the nature of the intervention and goals of the study.

- $\quad$ *Investigators should carefully review phase 2 trial results and choose a primary endpoint that is clinically meaningful and adequately powered for phase 3 .

- Investigators may move from phase 2 to phase 3 with at least adequate information on safety and tolerability, and 
should move forward if there is safety and tolerability in combination with (1) information regarding pharmacodynamically optimal dose, (2) evidence of target engagement, and/or (3) evidence of clinical efficacy.

- Investigators may assess biological effect and/or preliminary efficacy, even using novel methods (e.g., predictive algorithms or exploratory biomarkers), to support a decision to move a therapy to phase 3 trials.

- $\quad{ }^{*}$ When designing phase 3 trials, investigators should seek to use placebo-control before considering alternative designs.

- Investigators should work with biostatisticians to consider alternative designs.

- Investigators should use novel approaches to trial design to appropriately study gene and cell therapies with potentially invasive delivery or lifelong biological effects; efficacy should be part of the consideration for future phase $2 / 3$ novel trial designs, at the time a phase 1 trial is designed and implemented.

- *Investigators should publish all clinical trial results, negative or positive, so they are widely available to the ALS community.

\section{Beyond the traditional clinical trial}

\section{Background}

Despite positive effects in animal models or phase 2 trials, numerous promising therapeutics have failed during phase 3 studies over the last 20 years. Thus, a reappraisal of phase 3 methodologies is warranted because (1) many trials lack evidence that the therapy either reaches the CNS or engages the intended target, (2) drug-drug interactions between riluzole and the investigational drug may have affected the potential efficacy of the investigated drug, (3) more efficient and effective outcome measures are needed, including those that combine function and survival, and (4) phenotypic and genotypic heterogeneity of the ALS population has not been considered in inclusion criteria in previous trials. However, a lack of positive trials does not necessarily indicate a flawed process but may reflect lack of substantial efficacy, limited biomarkers, and limited sensitivity of the outcome measures. ${ }^{2}$

Improved regulatory trials, that aim to evaluate the efficacy of a new intervention in a well-controlled setting with the aim of obtaining regulatory approval, are required. ${ }^{2,3,44}$ The regulatory path is designed to protect patients and identify therapies that meet the required level of proof of efficacy.

The NIH definition of a pragmatic trial is one in which approved drugs are tested in real-world settings. ${ }^{45}$ Pragmatic trials may become a future consideration as new therapies are proven to affect the course of the disease.

\section{Guidelines}

- Investigators may include measures of target engagement and evidence of CNS penetration (if warranted) in the earliest PALS treated by the therapeutic molecule (phase 1).

- Investigators may seek to detect possible interactions of the investigational agent with riluzole. ${ }^{46}$
- Investigators should develop more efficient and effective outcome measures.

- Investigators should continue to aggressively pursue disease-modifying therapies, utilizing the scientific method that is inherent in regulatory compliant trials to increase the likelihood that therapies become available to PALS.

- Investigators should utilize pragmatic trial designs to compare established interventions and determine the external validity of positive phase 3 trials.

\section{Discussion}

A recent review of all clinical trials in ALS identified a critical need to update the original Airlie House consensus guidelines. ${ }^{2}$ These guidelines were published in 1999, early on in the ALS clinical trial experience, based on a conventional literature review with an informal "consensus" among ALS experts. ${ }^{1}$ The present project was undertaken to (1) update the earlier guidelines on the basis of intervening experience, (2) improve the efficiency and consistency of ALS clinical trials, and (3) use modern methods of examining evidence and establishing consensus. The modified Delphi process was applied, ${ }^{12}$ involving 140 international stakeholders with diverse interests and experience, in a multistage process. This approach was chosen to minimize bias since the option of a truly evidence-based approach was limited by the quality of available scientific evidence. The modified Delphi process is a formal consensus process that decreases the risk of bias being introduced into the guideline development process by reducing the influence of dominant personalities and groupthink, encouraging input from all participants, and increasing the probability that participants will change their opinions after considering other perspectives. ${ }^{12}$ Participants share their perspectives in a systematic way with the ultimate goal of achieving an unbiased consensus on a set of specific guidelines that are evidence-informed.

The 1999 guidelines briefly covered a number of statistical issues pertaining to phase 3 clinical trials. The 2018 guidelines include a more comprehensive statistical section that covers guidance for all phases of clinical research. Guidance on handling of dropouts, stratification, covariate adjustment, time-to-failure analyses, and lead-in designs has been updated and expanded, including discussion of predicted outcomes in design and analysis of trials. New guidance is provided in the following areas: pilot trial design; group-sequential methods application; pros and cons of adaptive trial designs; use of historical controls; biomarker development; combined analysis of survival and progression; use of linear mixed models for repeated measurements of longitudinal outcomes; specification and analysis of secondary outcomes; subgroup analyses; trial registration; data standardization; and data sharing.

ALS research has advanced considerably since publication of the previous guidelines. The introduction of 3 new areas of 
guidelines, namely, preclinical studies (section 1), biological and phenotypic heterogeneity (section 2), and biomarkers (section 6) reflects this.

In line with the present initiative, adherence to best practice guidelines and standards for preclinical treatment studies in ALS models and biomarker studies should enhance data accuracy and reproducibility, and therapeutic candidate selection before entering clinical trials.

Preclinical treatment studies have focused for years on the first and best studied ALS model, the mutated hSOD1 (present in only 1\%-2\% of PALS) transgenic mouse, but this has not led to effective therapies. Indeed, SOD1 transgenic models do not represent sporadic or other forms of genetic disease in patients. ${ }^{16,47,48}$ Newer models based on discoveries of many other genes focus almost entirely on genetic forms of ALS. ${ }^{47}$ Disease models that recapitulate key pathologies or biological processes seen in (subsets of) sporadic PALS must be prioritized for more successful translation of treatment efficacy from ALS disease models to patients. ${ }^{49,50}$ The recognition that ALS is etiologically and biologically heterogeneous implies that multiple disease models need to be generated to cover all ALS subsets. Yet, at the same time, clinical research involving patients has increasingly been recognized as essential to our understanding of disease heterogeneity and to the success of a precision medicine approach.

Gene therapy strategies in patients with a SOD1 or C9orf72 mutation represent the first successful examples of such a personalized approach. But for nonfamilial ALS, larger datasets are required. Such datasets are best collected and analyzed through international collaboration. Given the degree of disease heterogeneity, data from genetics, lifestyle and environmental studies, and patient-derived 2- and 3-dimensional (organoid) induced pluripotent stem cell models will be required. Such datasets are best combined with detailed phenotyping (including cognition) using internationally harmonized patient registries, neuroimaging and neurophysiologic studies, and biomarkers from biological fluids. This approach will provide essential tools to identify subsets of patients with shared etiology or biology and will facilitate targeted clinical trials by enabling the selection of patients most likely to benefit from a particular experimental therapeutic approach. Allowing patients and caregivers to participate in the design and execution of clinical trials is another important aspect of the 2018 guidelines.

Given the rate at which the field has advanced in recent years, we suggest a follow-up meeting to refine the guidelines within 4 years. Moreover, we view the 2018 clinical trial guidelines not as inflexible, final, or complete, but rather as an updated starting point for improving clinical trial design and accelerating the development of effective treatments for patients with ALS.

\section{Acknowledgment}

The authors acknowledge participation from the FDA (Wilson Bryan, MD), European Medicines Agency (Marion Haberkamp, $\mathrm{MD}$ ), and the Japanese Pharmaceuticals and Medical Devices Agency (Ken Sakushima, MD, PhD, Katsuhiko Ichimaru) for their scientific participation at the Airlie House Workshop. The authors thank the participants in the simultaneous Webinar conference and those who participated in the public comments. Allison Martin and David Zook (FaegreBD Consulting) and Lisa Bain organized the manuscript and references.

\section{Study funding}

The ALS Association (ALSA), ALS Canada, AISLA Onlus, ALS Hope Foundation, ALS Liga Belgium, The Anthony Senerchia, Jr., ALS Charitable Foundation, Avanir Pharmaceuticals, Inc., Biogen, Inc., Cytokinetics, Inc., International Alliance, Japanese ALS Association, The Judith \& Jean Pape Adams Charitable Foundation, Knopp Biosciences, Inc., Mitsubishi Tanabe Pharma Development America, Inc., Muscular Dystrophy Association (MDA), Muscular Dystrophy Association Australia (MDA), Motor Neurone Disease Association (MNDA), National Institutes of Neurological Disorders and Stroke (NINDS: 1U13NS093847), Sumitomo Dainippon Pharma Co., Ltd.

\section{Disclosure}

L. van den Berg serves on scientific advisory boards for the Biogen Idec, Cytokinetics, and Sarepta; received an educational grant from Shire; serves on the editorial boards of Amyotrophic Lateral Sclerosis and Frontotemporal Degeneration, the Journal of Neurology, Neurosurgery and Psychiatry, and the Journal of Neuromuscular Diseases; and receives research support from the Prinses Beatrix Spierfonds, Netherlands ALS Foundation, The European Community's Health Seventh Framework Programme (grant agreement 259867), The Netherlands Organisation for Health Research and Development (Vici Scheme, JPND [SOPHIA, STRENGTH, NETCALS, ALSCare]). E. Sorenson reports no disclosures relevant to the manuscript. G. Gronseth receives compensation from the American Academy of Neurology for activities related to being associate editor of Neurology ${ }^{\circledR}$, a member of the editorial advisory board for Brain \& Life, and chief methodologist for guideline development. J. Andrews: consultant for Cytokinetics, Biohaven, and Anelixis Therapeutics; received research grant funding from Neuraltus and Roche. R. Baloh reports no disclosures relevant to the manuscript. M. Benatar receives support from NIH (U54NS092091) for the CReATe Consortium. CReATe is part of Rare Diseases Clinical Research Network (RDCRN), an initiative of the Office of Rare Diseases Research (ORDR), NCATS. This consortium is funded through collaboration between NCATS and the NINDS. J. Berry consulted for MT Pharma and Denali Therapeutics and has received research support from Voyager Therapeutics, GSK, Cytokinetics, Brainstorm Cell Therapeutics, ALS One, ALS Association, Muscular Dystrophy Association, and NIH. A. Chio served on scientific advisory boards for Biogen Idec, Cytokinetics, Neuraltus, Italfarmaco, and Mitsubishi Tanabe. A. Genge consults for the following entities: Sanofi, Biogen, Novartis, ALS Pharma, AB 
Sciences, Wave Life Sciences, CSL Behring, Cytokinetics, Analexis, Orion, and Revalesio. A. Gubitz reports no disclosures. The findings and conclusions in this manuscript are the opinions of the authors and may not necessarily represent the official position of the National Institute of Neurological Disorders and Stroke. C. Lomen-Hoerth reports no disclosures relevant to the manuscript. E. Macklin served as a DSMB member and a Steering Committee member and received research funding from Acorda Therapeutics, served as a DSMB member for Shire Human Genetic Therapies, consultant to Myolex Inc., and Dr. Macklin's institution received research funding on his behalf from the Adolph Coors Foundation, the ALS Association, Autism Speaks, Cedars-Sinai Research Institute, the Michael J. Fox Foundation, and the Salah Foundation. C. McDermott: funded by the NIHR Sheffield Biomedical Research Centre (BRC). The views expressed are those of the author and not necessarily those of the NHS, the NIHR, or the Department of Health. P. Corcia: consultant for Roche. E. Pioro receives support from the Samuel J. and Connie M. Frankino Charitable Foundation, receives clinical trial and research funding from NIH/CDC, ALS Association, Iron Horse Diagnostics, and serves as consultant to Avanir Pharmaceuticals, Inc., Otsuka America, Inc., MT Pharma America, Inc., and Cytokinetics, Inc. J. Rosenfeld: consultant and speaker for MT Pharma and Strongbridge Biopharma; research funding, principal investigator for Mallinckrodt Pharma, FLEX Pharma. V. Silani serves on the scientific advisory board for Cytokinetics; V.S. serves on the editorial boards of Amyotrophic Lateral Sclerosis and Frontotemporal Degeneration, European Neurology, Frontiers in Neurology. M. Turner received funding from the Medical Research Council \& Motor Neurone Disease Association Lady Edith Wolfson Senior Fellowship (MR/ K01014X/1); paid consultancy for Genentech Inc. on ALS biomarkers (2017) and anonymous clients through GLG Consulting on the topic of ALS diagnosis, management, and biomarkers (2016-2018); scientific advisory board member of Orphazyme (2018); paid-in-kind for undertaking independent neurofilament study in ALS (kits provided by EUROIMMUN UK, 2017-2018). M. Weber served on scientific advisory boards for Biogen Idec, Merz Pharma Switzerland, CSL Behring, Pharnext, and Mitsubishi Tanabe. B. Rix Brooks has received personal compensation for consulting, serving on a scientific advisory board, speaking, or other activities with Mitsubishi Tanabe Pharma USA, Avanir, Biogren, and Biohaven. Dr. Brooks has received research support from MediciNova, Biohaven, Orion, Neuraltus, Cytokinetics, Santhera, Biogen, ITP Pharma, Acceleron, and Centers for Disease Control. R. Miller reports no disclosures relevant to the manuscript. $\mathrm{H}$. Mitsumoto received grants from CDC/ATSDR, MDA, SPF, NIH, ALSA, Adams Foundation, MNDA; advisory board: Cytokinetics, Mitsubishi-Tanabe, Biohaven, Sunovion, and Denali. Go to Neurology.org/N for full disclosures.

\section{Publication history}

Received by Neurology June 9, 2018. Accepted in final form December 6, 2018.

\section{Appendix 1 Authors}

\begin{tabular}{|c|c|c|c|}
\hline Name & Location & Role & Contribution \\
\hline $\begin{array}{l}\text { Leonard H. } \\
\text { van den } \\
\text { Berg, MD, } \\
\text { PhD }\end{array}$ & $\begin{array}{l}\text { University } \\
\text { Medical Center } \\
\text { Utrecht }\end{array}$ & $\begin{array}{l}\text { Co-chair of } \\
\text { section } 3\end{array}$ & $\begin{array}{l}\text { Contributed to all } \\
\text { stages of } \\
\text { developing the } \\
\text { guidelines, writing } \\
\text { of the manuscript }\end{array}$ \\
\hline $\begin{array}{l}\text { Eric } \\
\text { Sorenson, } \\
\text { MD }\end{array}$ & $\begin{array}{l}\text { Mayo Clinic, } \\
\text { Rochester }\end{array}$ & $\begin{array}{l}\text { Co-chair of } \\
\text { section } 3\end{array}$ & $\begin{array}{l}\text { Contributed to all } \\
\text { stages of } \\
\text { developing the } \\
\text { guidelines, writing } \\
\text { of the manuscript }\end{array}$ \\
\hline $\begin{array}{l}\text { Gary } \\
\text { Gronseth, } \\
\text { MD }\end{array}$ & $\begin{array}{l}\text { University of } \\
\text { Kansas Medical } \\
\text { Center }\end{array}$ & $\begin{array}{l}\text { Guideline } \\
\text { methodologist }\end{array}$ & $\begin{array}{l}\text { Contributed to all } \\
\text { stages of } \\
\text { developing the } \\
\text { guidelines, study } \\
\text { design, writing of } \\
\text { the manuscript }\end{array}$ \\
\hline $\begin{array}{l}\text { Eric A. } \\
\text { Macklin, } \\
\text { PhD }\end{array}$ & $\begin{array}{l}\text { Massachusetts } \\
\text { General } \\
\text { Hospital }\end{array}$ & $\begin{array}{l}\text { Chair of } \\
\text { section } 9 \text { and } \\
\text { member of } \\
\text { section } 1\end{array}$ & $\begin{array}{l}\text { Contributed to all } \\
\text { stages of } \\
\text { developing the } \\
\text { guidelines, writing } \\
\text { of the manuscript }\end{array}$ \\
\hline $\begin{array}{l}\text { Jinsy } \\
\text { Andrews, } \\
\text { MD, MSc }\end{array}$ & $\begin{array}{l}\text { Columbia } \\
\text { University }\end{array}$ & $\begin{array}{l}\text { Co-chair of } \\
\text { section } 7\end{array}$ & $\begin{array}{l}\text { Contributed to all } \\
\text { stages of } \\
\text { developing the } \\
\text { guidelines, critical } \\
\text { revision of the } \\
\text { manuscript }\end{array}$ \\
\hline $\begin{array}{l}\text { Robert H. } \\
\text { Baloh, MD, } \\
\text { PhD }\end{array}$ & Cedars-Sinai & $\begin{array}{l}\text { Co-chair of } \\
\text { section } 1\end{array}$ & $\begin{array}{l}\text { Contributed to all } \\
\text { stages of } \\
\text { developing the } \\
\text { guidelines, critical } \\
\text { revision of the } \\
\text { manuscript }\end{array}$ \\
\hline $\begin{array}{l}\text { Michael } \\
\text { Benatar, } \\
\text { MD, PhD }\end{array}$ & $\begin{array}{l}\text { University of } \\
\text { Miami }\end{array}$ & $\begin{array}{l}\text { Co-chair of } \\
\text { section } 6\end{array}$ & $\begin{array}{l}\text { Contributed to all } \\
\text { stages of } \\
\text { developing the } \\
\text { guidelines, critical } \\
\text { revision of the } \\
\text { manuscript }\end{array}$ \\
\hline $\begin{array}{l}\text { James Berry, } \\
\text { MD }\end{array}$ & $\begin{array}{l}\text { Massachusetts } \\
\text { General } \\
\text { Hospital }\end{array}$ & $\begin{array}{l}\text { Co-chair } \\
\text { member of } \\
\text { section } 7\end{array}$ & $\begin{array}{l}\text { Contributed to all } \\
\text { stages of } \\
\text { developing the } \\
\text { guidelines, critical } \\
\text { revision of the } \\
\text { manuscript }\end{array}$ \\
\hline $\begin{array}{l}\text { Adriano } \\
\text { Chio, MD }\end{array}$ & $\begin{array}{l}\text { University of } \\
\text { Torino and AOU } \\
\text { San Giovanni } \\
\text { Battista }\end{array}$ & $\begin{array}{l}\text { Co-chair of } \\
\text { section } 5\end{array}$ & $\begin{array}{l}\text { Contributed to all } \\
\text { stages of } \\
\text { developing the } \\
\text { guidelines, critical } \\
\text { revision of the } \\
\text { manuscript }\end{array}$ \\
\hline $\begin{array}{l}\text { Philippe } \\
\text { Corcia, MD, } \\
\text { PhD }\end{array}$ & $\begin{array}{l}\text { University of } \\
\text { Tours }\end{array}$ & $\begin{array}{l}\text { Co-chair of } \\
\text { section } 8\end{array}$ & $\begin{array}{l}\text { Contributed to all } \\
\text { stages of } \\
\text { developing the } \\
\text { guidelines, critical } \\
\text { revision of the } \\
\text { manuscript }\end{array}$ \\
\hline $\begin{array}{l}\text { Angela } \\
\text { Genge, MD }\end{array}$ & $\begin{array}{l}\text { Montreal } \\
\text { Neurological } \\
\text { Institute and } \\
\text { Hospital }\end{array}$ & $\begin{array}{l}\text { Co-chair of } \\
\text { section } 8\end{array}$ & $\begin{array}{l}\text { Contributed to all } \\
\text { stages of } \\
\text { developing the } \\
\text { guidelines, critical } \\
\text { revision of the } \\
\text { manuscript }\end{array}$ \\
\hline
\end{tabular}


Appendix 1 (continued)

\begin{tabular}{|c|c|c|c|}
\hline Name & Location & Role & Contribution \\
\hline $\begin{array}{l}\text { Amelie K. } \\
\text { Gubitz, PhD }\end{array}$ & $\begin{array}{l}\text { National } \\
\text { Institute of } \\
\text { Neurological } \\
\text { Disorders and } \\
\text { Stroke }\end{array}$ & $\begin{array}{l}\text { Co-chair of } \\
\text { section } 1\end{array}$ & $\begin{array}{l}\text { Contributed to all } \\
\text { stages of } \\
\text { developing the } \\
\text { guidelines, critical } \\
\text { revision of the } \\
\text { manuscript }\end{array}$ \\
\hline $\begin{array}{l}\text { Catherine } \\
\text { Lomen- } \\
\text { Horth, MD, } \\
\text { PhD }\end{array}$ & $\begin{array}{l}\text { University of } \\
\text { California, San } \\
\text { Francisco }\end{array}$ & $\begin{array}{l}\text { Co-chair of } \\
\text { section } 2\end{array}$ & $\begin{array}{l}\text { Contributed to all } \\
\text { stages of } \\
\text { developing the } \\
\text { guidelines, critical } \\
\text { revision of the } \\
\text { manuscript }\end{array}$ \\
\hline $\begin{array}{l}\text { Christopher } \\
\text { J. } \\
\text { McDermott, } \\
\text { MD }\end{array}$ & $\begin{array}{l}\text { University of } \\
\text { Sheffield }\end{array}$ & $\begin{array}{l}\text { Co-chair of } \\
\text { section } 4\end{array}$ & $\begin{array}{l}\text { Contributed to all } \\
\text { stages of } \\
\text { developing the } \\
\text { guidelines, critical } \\
\text { revision of the } \\
\text { manuscript }\end{array}$ \\
\hline $\begin{array}{l}\text { Erik P. Pioro, } \\
\text { MD, PhD }\end{array}$ & Cleveland Clinic & $\begin{array}{l}\text { Co-chair of } \\
\text { section } 5\end{array}$ & $\begin{array}{l}\text { Contributed to all } \\
\text { stages of } \\
\text { developing the } \\
\text { guidelines, critical } \\
\text { revision of the } \\
\text { manuscript }\end{array}$ \\
\hline $\begin{array}{l}\text { Jeffrey } \\
\text { Rosenfeld, } \\
\text { PhD, MD }\end{array}$ & $\begin{array}{l}\text { Loma Linda } \\
\text { University } \\
\text { Health }\end{array}$ & $\begin{array}{l}\text { Co-chair of } \\
\text { section } 4\end{array}$ & $\begin{array}{l}\text { Contributed to all } \\
\text { stages of } \\
\text { developing the } \\
\text { guidelines, critical } \\
\text { revision of the } \\
\text { manuscript }\end{array}$ \\
\hline $\begin{array}{l}\text { Vincenzo } \\
\text { Silani, MD }\end{array}$ & $\begin{array}{l}\text { Istituto } \\
\text { Auxologico } \\
\text { Italiano, IRCCS } \\
\text { and University } \\
\text { of Milan } \\
\text { Medical School }\end{array}$ & $\begin{array}{l}\text { Co-chair of } \\
\text { section } 2\end{array}$ & $\begin{array}{l}\text { Contributed to all } \\
\text { stages of } \\
\text { developing the } \\
\text { guidelines, critical } \\
\text { revision of the } \\
\text { manuscript }\end{array}$ \\
\hline $\begin{array}{l}\text { Martin R. } \\
\text { Turner, } \\
\text { MBBS, PhD }\end{array}$ & $\begin{array}{l}\text { University of } \\
\text { Oxford }\end{array}$ & $\begin{array}{l}\text { Co-chair of } \\
\text { section } 6\end{array}$ & $\begin{array}{l}\text { Contributed to all } \\
\text { stages of } \\
\text { developing the } \\
\text { guidelines, critical } \\
\text { revision of the } \\
\text { manuscript }\end{array}$ \\
\hline $\begin{array}{l}\text { Markus } \\
\text { Weber, MD }\end{array}$ & $\begin{array}{l}\text { St. Gallen } \\
\text { Cantonal } \\
\text { Hospital }\end{array}$ & $\begin{array}{l}\text { Co-chair of } \\
\text { section } 6\end{array}$ & $\begin{array}{l}\text { Contributed to all } \\
\text { stages of } \\
\text { developing the } \\
\text { guidelines, critical } \\
\text { revision of the } \\
\text { manuscript }\end{array}$ \\
\hline $\begin{array}{l}\text { Benjamin } \\
\text { Rix Brooks, } \\
\text { MD }\end{array}$ & $\begin{array}{l}\text { University of } \\
\text { North Carolina } \\
\text { School of } \\
\text { Medicine, } \\
\text { Carolinas } \\
\text { Medical Center }\end{array}$ & Author & $\begin{array}{l}\text { Contributed to all } \\
\text { stages of } \\
\text { developing the } \\
\text { guidelines, writing } \\
\text { of the manuscript }\end{array}$ \\
\hline $\begin{array}{l}\text { Robert G. } \\
\text { Miller, MD }\end{array}$ & $\begin{array}{l}\text { California } \\
\text { Pacific Medical } \\
\text { Center, Forbes } \\
\text { Norris MDA/ } \\
\text { ALS Research } \\
\text { Center }\end{array}$ & Author & $\begin{array}{l}\text { Contributed to all } \\
\text { stages of } \\
\text { developing the } \\
\text { guidelines, writing } \\
\text { of the manuscript }\end{array}$ \\
\hline $\begin{array}{l}\text { Hiroshi } \\
\text { Mitsumoto, } \\
\text { MD, DSc }\end{array}$ & $\begin{array}{l}\text { Columbia } \\
\text { University } \\
\text { Medical Center }\end{array}$ & Supervision & $\begin{array}{l}\text { Contributed to all } \\
\text { stages of } \\
\text { developing the } \\
\text { guidelines, writing } \\
\text { of the manuscript }\end{array}$ \\
\hline
\end{tabular}

Appendix 2 Coinvestigators

\begin{tabular}{|c|c|c|c|}
\hline Name & Location & Role & Contribution \\
\hline $\begin{array}{l}\text { Stanley H. } \\
\text { Appel, MD }\end{array}$ & $\begin{array}{l}\text { Houston Methodist } \\
\text { Neurological Institute }\end{array}$ & $\begin{array}{l}\text { Member } \\
\text { of } \\
\text { section } 1\end{array}$ & $\begin{array}{l}\text { Contributed to } \\
\text { all stages of } \\
\text { developing the } \\
\text { guidelines }\end{array}$ \\
\hline $\begin{array}{l}\text { Haruhiko } \\
\text { Banno, MD, } \\
\text { PhD }\end{array}$ & $\begin{array}{l}\text { University of } \\
\text { Massachusetts Medical } \\
\text { School }\end{array}$ & $\begin{array}{l}\text { Member } \\
\text { of } \\
\text { section } 1\end{array}$ & $\begin{array}{l}\text { Contributed to } \\
\text { all stages of } \\
\text { developing the } \\
\text { guidelines }\end{array}$ \\
\hline $\begin{array}{l}\text { Lucie Bruijn, } \\
\text { PhD }\end{array}$ & The ALS Association & $\begin{array}{l}\text { Member } \\
\text { of } \\
\text { section } 1\end{array}$ & $\begin{array}{l}\text { Contributed to } \\
\text { all stages of } \\
\text { developing the } \\
\text { guidelines }\end{array}$ \\
\hline $\begin{array}{l}\text { Jean-Pierre } \\
\text { Julien, PhD }\end{array}$ & Laval University & $\begin{array}{l}\text { Member } \\
\text { of } \\
\text { section } 1\end{array}$ & $\begin{array}{l}\text { Contributed to } \\
\text { all stages of } \\
\text { developing the } \\
\text { guidelines }\end{array}$ \\
\hline $\begin{array}{l}\text { Steve Perrin, } \\
\text { PhD }\end{array}$ & $\begin{array}{l}\text { ALS Therapy } \\
\text { Development Institute }\end{array}$ & $\begin{array}{l}\text { Member } \\
\text { of } \\
\text { section } 1\end{array}$ & $\begin{array}{l}\text { Contributed to } \\
\text { all stages of } \\
\text { developing the } \\
\text { guidelines }\end{array}$ \\
\hline $\begin{array}{l}\text { Pamela } \\
\text { Shaw, MD, } \\
\text { FRCP }\end{array}$ & University of Sheffield & $\begin{array}{l}\text { Member } \\
\text { of } \\
\text { section } 1\end{array}$ & $\begin{array}{l}\text { Contributed to } \\
\text { all stages of } \\
\text { developing the } \\
\text { guidelines }\end{array}$ \\
\hline $\begin{array}{l}\text { Gen Sobue, } \\
\text { MD, PhD }\end{array}$ & Nagoya University & $\begin{array}{l}\text { Member } \\
\text { of } \\
\text { section } 1\end{array}$ & $\begin{array}{l}\text { Contributed to } \\
\text { all stages of } \\
\text { developing the } \\
\text { guidelines }\end{array}$ \\
\hline $\begin{array}{l}\text { Kevin Talbot, } \\
\text { DPhil, FRCP }\end{array}$ & University of Oxford & $\begin{array}{l}\text { Member } \\
\text { of } \\
\text { section } 1\end{array}$ & $\begin{array}{l}\text { Contributed to } \\
\text { all stages of } \\
\text { developing the } \\
\text { guidelines }\end{array}$ \\
\hline $\begin{array}{l}\text { Bryan } \\
\text { Traynor, MD, } \\
\text { PhD }\end{array}$ & $\begin{array}{l}\text { National Institute on } \\
\text { Aging }\end{array}$ & $\begin{array}{l}\text { Member } \\
\text { of } \\
\text { section } 1\end{array}$ & $\begin{array}{l}\text { Contributed to } \\
\text { all stages of } \\
\text { developing the } \\
\text { guidelines }\end{array}$ \\
\hline $\begin{array}{l}\text { Jeffrey } \\
\text { Rothstein, } \\
\text { MD, PhD }\end{array}$ & $\begin{array}{l}\text { Johns Hopkins } \\
\text { University }\end{array}$ & $\begin{array}{l}\text { Member } \\
\text { of } \\
\text { section } 1\end{array}$ & $\begin{array}{l}\text { Contributed to } \\
\text { all stages of } \\
\text { developing the } \\
\text { guidelines }\end{array}$ \\
\hline $\begin{array}{l}\text { Naoki } \\
\text { Atsuta, MD, } \\
\text { PhD }\end{array}$ & Nagoya University & $\begin{array}{l}\text { Member } \\
\text { of } \\
\text { section } 1\end{array}$ & $\begin{array}{l}\text { Contributed to } \\
\text { all stages of } \\
\text { developing the } \\
\text { guidelines }\end{array}$ \\
\hline $\begin{array}{l}\text { Wim } \\
\text { Robberecht, } \\
\text { MD, PhD }\end{array}$ & KU Leuven & $\begin{array}{l}\text { Member } \\
\text { of } \\
\text { section } 1\end{array}$ & $\begin{array}{l}\text { Contributed to } \\
\text { all stages of } \\
\text { developing the } \\
\text { guidelines }\end{array}$ \\
\hline $\begin{array}{l}\text { Peter Munch } \\
\text { Andersen, } \\
\text { MD, PhD }\end{array}$ & Umea University & $\begin{array}{l}\text { Member } \\
\text { of } \\
\text { section } 2\end{array}$ & $\begin{array}{l}\text { Contributed to } \\
\text { all stages of } \\
\text { developing the } \\
\text { guidelines }\end{array}$ \\
\hline $\begin{array}{l}\text { Michael } \\
\text { Bradburn, } \\
\text { MSc }\end{array}$ & University of Sheffield & $\begin{array}{l}\text { Member } \\
\text { of } \\
\text { sections } \\
2 \text { and } 9\end{array}$ & $\begin{array}{l}\text { Contributed to } \\
\text { all stages of } \\
\text { developing the } \\
\text { guidelines }\end{array}$ \\
\hline $\begin{array}{l}\text { Walter G. } \\
\text { Bradley, MD, } \\
\text { FRCP }\end{array}$ & University of Miami & $\begin{array}{l}\text { Member } \\
\text { of } \\
\text { section } 2\end{array}$ & $\begin{array}{l}\text { Contributed to } \\
\text { all stages of } \\
\text { developing the } \\
\text { guidelines }\end{array}$ \\
\hline
\end{tabular}

Continued 
Appendix 2 (continued)

\begin{tabular}{|c|c|c|c|}
\hline Name & Location & Role & Contribution \\
\hline $\begin{array}{l}\text { Eva L. } \\
\text { Feldman, } \\
\text { MD, PhD }\end{array}$ & University of Michigan & $\begin{array}{l}\text { Member } \\
\text { of } \\
\text { section } 2\end{array}$ & $\begin{array}{l}\text { Contributed to } \\
\text { all stages of } \\
\text { developing the } \\
\text { guidelines }\end{array}$ \\
\hline $\begin{array}{l}\text { Omar } \\
\text { Jawdat, MD }\end{array}$ & Kansas University & $\begin{array}{l}\text { Member } \\
\text { of } \\
\text { section } 2\end{array}$ & $\begin{array}{l}\text { Contributed to } \\
\text { all stages of } \\
\text { developing the } \\
\text { guidelines }\end{array}$ \\
\hline $\begin{array}{l}\text { Jennifer } \\
\text { Murphy, PhD }\end{array}$ & $\begin{array}{l}\text { INC Research/ALS } \\
\text { Center at University of } \\
\text { California, San } \\
\text { Francisco }\end{array}$ & $\begin{array}{l}\text { Member } \\
\text { of } \\
\text { section } 2\end{array}$ & $\begin{array}{l}\text { Contributed to } \\
\text { all stages of } \\
\text { developing the } \\
\text { guidelines }\end{array}$ \\
\hline Jess Rabourn & $\begin{array}{l}\text { ALS Emergency } \\
\text { Treatment Fund }\end{array}$ & $\begin{array}{l}\text { Member } \\
\text { of } \\
\text { section } 2\end{array}$ & $\begin{array}{l}\text { Contributed to } \\
\text { all stages of } \\
\text { developing the } \\
\text { guidelines }\end{array}$ \\
\hline $\begin{array}{l}\text { Christen } \\
\text { Shoesmith, } \\
\text { MD }\end{array}$ & $\begin{array}{l}\text { Western University, } \\
\text { London, Canada }\end{array}$ & $\begin{array}{l}\text { Member } \\
\text { of } \\
\text { section } 2\end{array}$ & $\begin{array}{l}\text { Contributed to } \\
\text { all stages of } \\
\text { developing the } \\
\text { guidelines }\end{array}$ \\
\hline $\begin{array}{l}\text { Michael A. } \\
\text { van Es, MD, } \\
\text { PhD }\end{array}$ & $\begin{array}{l}\text { University Medical } \\
\text { Center Utrecht }\end{array}$ & $\begin{array}{l}\text { Member } \\
\text { of } \\
\text { section } 2\end{array}$ & $\begin{array}{l}\text { Contributed to } \\
\text { all stages of } \\
\text { developing the } \\
\text { guidelines }\end{array}$ \\
\hline $\begin{array}{l}\text { Susan } \\
\text { Woolley- } \\
\text { Levine, PhD }\end{array}$ & $\begin{array}{l}\text { California Pacific } \\
\text { Medical Center, Forbes } \\
\text { Norris ALS Research } \\
\text { and Treatment Center }\end{array}$ & $\begin{array}{l}\text { Member } \\
\text { of } \\
\text { section } 2\end{array}$ & $\begin{array}{l}\text { Contributed to } \\
\text { all stages of } \\
\text { developing the } \\
\text { guidelines }\end{array}$ \\
\hline $\begin{array}{l}\text { Benjamin Rix } \\
\text { Brooks, MD }\end{array}$ & $\begin{array}{l}\text { University of North } \\
\text { Carolina School of } \\
\text { Medicine, Carolinas } \\
\text { Medical Center }\end{array}$ & $\begin{array}{l}\text { Member } \\
\text { of } \\
\text { section } 2\end{array}$ & $\begin{array}{l}\text { Contributed to } \\
\text { all stages of } \\
\text { developing the } \\
\text { guidelines }\end{array}$ \\
\hline $\begin{array}{l}\text { Orla } \\
\text { Hardiman, } \\
\text { MD }\end{array}$ & Trinity College Dublin & $\begin{array}{l}\text { Member } \\
\text { of } \\
\text { section } 2\end{array}$ & $\begin{array}{l}\text { Contributed to } \\
\text { all stages of } \\
\text { developing the } \\
\text { guidelines }\end{array}$ \\
\hline $\begin{array}{l}\text { Nathan } \\
\text { Staff, MD, } \\
\text { PhD }\end{array}$ & Mayo Clinic, Rochester & $\begin{array}{l}\text { Member } \\
\text { of } \\
\text { section } 2\end{array}$ & $\begin{array}{l}\text { Contributed to } \\
\text { all stages of } \\
\text { developing the } \\
\text { guidelines }\end{array}$ \\
\hline $\begin{array}{l}\text { Giancarlo } \\
\text { Logroscino, } \\
\text { MD }\end{array}$ & $\begin{array}{l}\text { University of Bari Aldo } \\
\text { Moro at Card. G. Panico } \\
\text { Hospital }\end{array}$ & $\begin{array}{l}\text { Member } \\
\text { of } \\
\text { section } 2\end{array}$ & $\begin{array}{l}\text { Contributed to } \\
\text { all stages of } \\
\text { developing the } \\
\text { guidelines }\end{array}$ \\
\hline $\begin{array}{l}\text { Michael } \\
\text { Strong, MD }\end{array}$ & $\begin{array}{l}\text { Western University, } \\
\text { London, Canada }\end{array}$ & $\begin{array}{l}\text { Member } \\
\text { of } \\
\text { section } 2\end{array}$ & $\begin{array}{l}\text { Contributed to } \\
\text { all stages of } \\
\text { developing the } \\
\text { guidelines }\end{array}$ \\
\hline $\begin{array}{l}\text { Ammar } \\
\text { Al-Chalabi, } \\
\text { MBChB, PhD }\end{array}$ & $\begin{array}{l}\text { Maurice Wohl Clinical } \\
\text { Neuroscience Institute, } \\
\text { King's College London, } \\
\text { Department of Basic } \\
\text { and Clinical } \\
\text { Neuroscience, UK; } \\
\text { King's College Hospital, } \\
\text { Denmark Hill, London, } \\
\text { UK }\end{array}$ & $\begin{array}{l}\text { Member } \\
\text { of } \\
\text { section } 3\end{array}$ & $\begin{array}{l}\text { Contributed to } \\
\text { all stages of } \\
\text { developing the } \\
\text { guidelines }\end{array}$ \\
\hline $\begin{array}{l}\text { Jonathan } \\
\text { Cooper- } \\
\text { Knock, } \\
\text { MBBS, PhD }\end{array}$ & University of Sheffield & $\begin{array}{l}\text { Member } \\
\text { of } \\
\text { section } 3\end{array}$ & $\begin{array}{l}\text { Contributed to } \\
\text { all stages of } \\
\text { developing the } \\
\text { guidelines }\end{array}$ \\
\hline
\end{tabular}

Appendix 2 (continued)

\begin{tabular}{|c|c|c|c|}
\hline Name & Location & Role & Contribution \\
\hline $\begin{array}{l}\text { P. Nigel } \\
\text { Leigh, MBBS, } \\
\text { PhD }\end{array}$ & $\begin{array}{l}\text { Brighton and Sussex } \\
\text { Medical School }\end{array}$ & $\begin{array}{l}\text { Member } \\
\text { of } \\
\text { section } 3\end{array}$ & $\begin{array}{l}\text { Contributed to } \\
\text { all stages of } \\
\text { developing the } \\
\text { guidelines }\end{array}$ \\
\hline $\begin{array}{l}\text { Dan Moore, } \\
\text { PhD }\end{array}$ & $\begin{array}{l}\text { California Pacific } \\
\text { Medical Center }\end{array}$ & $\begin{array}{l}\text { Member } \\
\text { of } \\
\text { sections } \\
3 \text { and } 9\end{array}$ & $\begin{array}{l}\text { Contributed to } \\
\text { all stages of } \\
\text { developing the } \\
\text { guidelines }\end{array}$ \\
\hline $\begin{array}{l}\text { Sabrina } \\
\text { Paganoni, } \\
\text { MD, PhD }\end{array}$ & $\begin{array}{l}\text { Massachusetts General } \\
\text { Hospital }\end{array}$ & $\begin{array}{l}\text { Member } \\
\text { of } \\
\text { section } 3\end{array}$ & $\begin{array}{l}\text { Contributed to } \\
\text { all stages of } \\
\text { developing the } \\
\text { guidelines }\end{array}$ \\
\hline $\begin{array}{l}\text { Susanne } \\
\text { Petri, MD }\end{array}$ & $\begin{array}{l}\text { Hanover Medical } \\
\text { School }\end{array}$ & $\begin{array}{l}\text { Member } \\
\text { of } \\
\text { section } 3\end{array}$ & $\begin{array}{l}\text { Contributed to } \\
\text { all stages of } \\
\text { developing the } \\
\text { guidelines }\end{array}$ \\
\hline $\begin{array}{l}\text { J. Steven } \\
\text { Reznick, PhD }\end{array}$ & $\begin{array}{l}\text { Formerly with Center } \\
\text { for Developmental } \\
\text { Science; Carolina } \\
\text { Institute of } \\
\text { Developmental } \\
\text { Disabilities; and the } \\
\text { Frank Porter Graham } \\
\text { Child Development } \\
\text { Institute (passed } \\
\text { away from ALS in } \\
\text { 2016) }\end{array}$ & $\begin{array}{l}\text { Member } \\
\text { of } \\
\text { section } 3\end{array}$ & $\begin{array}{l}\text { Contributed to } \\
\text { all stages of } \\
\text { developing the } \\
\text { guidelines }\end{array}$ \\
\hline $\begin{array}{l}\text { Jeremy } \\
\text { Shefner, MD, } \\
\text { PhD }\end{array}$ & $\begin{array}{l}\text { Barrow Neurological } \\
\text { Institute and Dignity } \\
\text { Health St. Joseph's } \\
\text { Hospital and Medical } \\
\text { Center, Phoenix }\end{array}$ & $\begin{array}{l}\text { Member } \\
\text { of } \\
\text { section } 3\end{array}$ & $\begin{array}{l}\text { Contributed to } \\
\text { all stages of } \\
\text { developing the } \\
\text { guidelines }\end{array}$ \\
\hline $\begin{array}{l}\text { Hiide } \\
\text { Yoshino, MD }\end{array}$ & $\begin{array}{l}\text { Yoshino Neurology } \\
\text { Clinic }\end{array}$ & $\begin{array}{l}\text { Member } \\
\text { of } \\
\text { section } 3\end{array}$ & $\begin{array}{l}\text { Contributed to } \\
\text { all stages of } \\
\text { developing the } \\
\text { guidelines }\end{array}$ \\
\hline $\begin{array}{l}\text { Teepu } \\
\text { Siddique, MD }\end{array}$ & $\begin{array}{l}\text { Northwestern } \\
\text { University, Feinberg } \\
\text { School of Medicine }\end{array}$ & $\begin{array}{l}\text { Member } \\
\text { of } \\
\text { section } 3\end{array}$ & $\begin{array}{l}\text { Contributed to } \\
\text { all stages of } \\
\text { developing the } \\
\text { guidelines }\end{array}$ \\
\hline $\begin{array}{l}\text { Senda } \\
\text { Ajroud-Driss, } \\
\text { MD }\end{array}$ & $\begin{array}{l}\text { Northwestern } \\
\text { University, Feinberg } \\
\text { School of Medicine }\end{array}$ & $\begin{array}{l}\text { Member } \\
\text { of } \\
\text { section } 4\end{array}$ & $\begin{array}{l}\text { Contributed to } \\
\text { all stages of } \\
\text { developing the } \\
\text { guidelines }\end{array}$ \\
\hline $\begin{array}{l}\text { Ettore Beghi, } \\
\text { MD }\end{array}$ & $\begin{array}{l}\text { Mario Negri Institute } \\
\text { for Pharmacological } \\
\text { Research }\end{array}$ & $\begin{array}{l}\text { Member } \\
\text { of } \\
\text { section } 4\end{array}$ & $\begin{array}{l}\text { Contributed to } \\
\text { all stages of } \\
\text { developing the } \\
\text { guidelines }\end{array}$ \\
\hline $\begin{array}{l}\text { Stephen A. } \\
\text { Goutman, } \\
\text { MD }\end{array}$ & University of Michigan & $\begin{array}{l}\text { Member } \\
\text { of } \\
\text { section } 4\end{array}$ & $\begin{array}{l}\text { Contributed to } \\
\text { all stages of } \\
\text { developing the } \\
\text { guidelines }\end{array}$ \\
\hline $\begin{array}{l}\text { Daragh } \\
\text { Heitzman, } \\
\text { MD }\end{array}$ & Texas Neurology & $\begin{array}{l}\text { Member } \\
\text { of } \\
\text { section } 4\end{array}$ & $\begin{array}{l}\text { Contributed to } \\
\text { all stages of } \\
\text { developing the } \\
\text { guidelines }\end{array}$ \\
\hline $\begin{array}{l}\text { Justin Kwan, } \\
\text { MD }\end{array}$ & $\begin{array}{l}\text { Temple Neurosciences } \\
\text { Center }\end{array}$ & $\begin{array}{l}\text { Member } \\
\text { of } \\
\text { section } 4\end{array}$ & $\begin{array}{l}\text { Contributed to } \\
\text { all stages of } \\
\text { developing the } \\
\text { guidelines }\end{array}$ \\
\hline
\end{tabular}


Appendix 2 (continued)

\begin{tabular}{|c|c|c|c|}
\hline Name & Location & Role & Contribution \\
\hline $\begin{array}{l}\text { Björn } \\
\text { Oskarsson, } \\
\text { MD }\end{array}$ & $\begin{array}{l}\text { Mayo Clinic, } \\
\text { Jacksonville }\end{array}$ & $\begin{array}{l}\text { Member } \\
\text { of } \\
\text { section } 4\end{array}$ & $\begin{array}{l}\text { Contributed to } \\
\text { all stages of } \\
\text { developing the } \\
\text { guidelines }\end{array}$ \\
\hline $\begin{array}{l}\text { Gary Pattee, } \\
\text { MD }\end{array}$ & Neurology Associates & $\begin{array}{l}\text { Member } \\
\text { of } \\
\text { section } 4\end{array}$ & $\begin{array}{l}\text { Contributed to } \\
\text { all stages of } \\
\text { developing the } \\
\text { guidelines }\end{array}$ \\
\hline $\begin{array}{l}\text { Nicholas } \\
\text { Maragakis, } \\
\text { MD }\end{array}$ & $\begin{array}{l}\text { Johns Hopkins } \\
\text { Medicine }\end{array}$ & $\begin{array}{l}\text { Member } \\
\text { of } \\
\text { section } 4\end{array}$ & $\begin{array}{l}\text { Contributed to } \\
\text { all stages of } \\
\text { developing the } \\
\text { guidelines }\end{array}$ \\
\hline $\begin{array}{l}\text { Paul } \\
\text { Barkhaus, } \\
\text { MD }\end{array}$ & $\begin{array}{l}\text { Medical College of } \\
\text { Wisconsin }\end{array}$ & $\begin{array}{l}\text { Member } \\
\text { of } \\
\text { section } 5\end{array}$ & $\begin{array}{l}\text { Contributed to } \\
\text { all stages of } \\
\text { developing the } \\
\text { guidelines }\end{array}$ \\
\hline $\begin{array}{l}\text { Richard } \\
\text { Bedlack, MD, } \\
\text { PhD }\end{array}$ & Duke University & $\begin{array}{l}\text { Member } \\
\text { of } \\
\text { section } 5\end{array}$ & $\begin{array}{l}\text { Contributed to } \\
\text { all stages of } \\
\text { developing the } \\
\text { guidelines }\end{array}$ \\
\hline $\begin{array}{l}\text { Rebecca } \\
\text { Broad, MD }\end{array}$ & $\begin{array}{l}\text { Brighton and Sussex } \\
\text { Medical School }\end{array}$ & $\begin{array}{l}\text { Member } \\
\text { of } \\
\text { section } 5\end{array}$ & $\begin{array}{l}\text { Contributed to } \\
\text { all stages of } \\
\text { developing the } \\
\text { guidelines }\end{array}$ \\
\hline $\begin{array}{l}\text { Dominic Fee, } \\
\text { MD }\end{array}$ & $\begin{array}{l}\text { Medical College of } \\
\text { Wisconsin }\end{array}$ & $\begin{array}{l}\text { Member } \\
\text { of } \\
\text { section } 5\end{array}$ & $\begin{array}{l}\text { Contributed to } \\
\text { all stages of } \\
\text { developing the } \\
\text { guidelines }\end{array}$ \\
\hline $\begin{array}{l}\text { Christian } \\
\text { Lunetta, MD }\end{array}$ & $\begin{array}{l}\text { EUPPALS, European } \\
\text { Organization for } \\
\text { Professionals and } \\
\text { Patients with ALS and } \\
\text { Italian ALS } \\
\text { Association (AISLA } \\
\text { Onlus) }\end{array}$ & $\begin{array}{l}\text { Member } \\
\text { of } \\
\text { section } 5\end{array}$ & $\begin{array}{l}\text { Contributed to } \\
\text { all stages of } \\
\text { developing the } \\
\text { guidelines }\end{array}$ \\
\hline $\begin{array}{l}\text { Paul Mehta, } \\
\text { MD }\end{array}$ & $\begin{array}{l}\text { Centers for Disease } \\
\text { Control, Agency for } \\
\text { Toxic Substances and } \\
\text { Disease Registry } \\
\text { (ATSDR) }\end{array}$ & $\begin{array}{l}\text { Member } \\
\text { of } \\
\text { section } 5\end{array}$ & $\begin{array}{l}\text { Contributed to } \\
\text { all stages of } \\
\text { developing the } \\
\text { guidelines }\end{array}$ \\
\hline $\begin{array}{l}\text { Mieko Ogino, } \\
\text { MD }\end{array}$ & Kitasato University & $\begin{array}{l}\text { Member } \\
\text { of } \\
\text { section } 5\end{array}$ & $\begin{array}{l}\text { Contributed to } \\
\text { all stages of } \\
\text { developing the } \\
\text { guidelines }\end{array}$ \\
\hline $\begin{array}{l}\text { Charity } \\
\text { Patterson, } \\
\text { PhD }\end{array}$ & $\begin{array}{l}\text { School or Health and } \\
\text { Rehabilitation Sciences, } \\
\text { University of Pittsburgh }\end{array}$ & $\begin{array}{l}\text { Member } \\
\text { of } \\
\text { sections } \\
5 \text { and } 9\end{array}$ & $\begin{array}{l}\text { Contributed to } \\
\text { all stages of } \\
\text { developing the } \\
\text { guidelines }\end{array}$ \\
\hline $\begin{array}{l}\text { Paul Wicks, } \\
\text { PhD }\end{array}$ & PatientsLikeMe & $\begin{array}{l}\text { Member } \\
\text { of } \\
\text { section } 5\end{array}$ & $\begin{array}{l}\text { Contributed to } \\
\text { all stages of } \\
\text { developing the } \\
\text { guidelines }\end{array}$ \\
\hline $\begin{array}{l}\text { Kevin } \\
\text { Horton, } \\
\text { DrPH, MSPH }\end{array}$ & $\begin{array}{l}\text { Centers for Disease } \\
\text { Control, Agency for } \\
\text { Toxic Substances and } \\
\text { Disease Registry } \\
\text { (ATSDR) }\end{array}$ & $\begin{array}{l}\text { Member } \\
\text { of } \\
\text { section } 5\end{array}$ & $\begin{array}{l}\text { Contributed to } \\
\text { all stages of } \\
\text { developing the } \\
\text { guidelines }\end{array}$ \\
\hline Becky Kidd & Patient advocate & $\begin{array}{l}\text { Member } \\
\text { of } \\
\text { section } 5\end{array}$ & $\begin{array}{l}\text { Contributed to } \\
\text { all stages of } \\
\text { developing the } \\
\text { guidelines }\end{array}$ \\
\hline
\end{tabular}

Appendix 2 (continued)

\begin{tabular}{|c|c|c|c|}
\hline Name & Location & Role & Contribution \\
\hline Rick Isaacs & $\begin{array}{l}\text { Patient advocate } \\
\text { (passed away from ALS } \\
\text { in 2017) }\end{array}$ & $\begin{array}{l}\text { Member } \\
\text { of } \\
\text { section } 5\end{array}$ & $\begin{array}{l}\text { Contributed to } \\
\text { all stages of } \\
\text { developing the } \\
\text { guidelines }\end{array}$ \\
\hline Evy Reviers & $\begin{array}{l}\text { EUPPALS, European } \\
\text { Organization for } \\
\text { Professionals and } \\
\text { Patients with ALS }\end{array}$ & $\begin{array}{l}\text { Member } \\
\text { of } \\
\text { section } 5\end{array}$ & $\begin{array}{l}\text { Contributed to } \\
\text { all stages of } \\
\text { developing the } \\
\text { guidelines }\end{array}$ \\
\hline Cris Simon & PatientsLikeMe & $\begin{array}{l}\text { Member } \\
\text { of } \\
\text { section } 5\end{array}$ & $\begin{array}{l}\text { Contributed to } \\
\text { all stages of } \\
\text { developing the } \\
\text { guidelines }\end{array}$ \\
\hline $\begin{array}{l}\text { Edward } \\
\text { Tessaro }\end{array}$ & Patient advocate & $\begin{array}{l}\text { Member } \\
\text { of } \\
\text { section } 5\end{array}$ & $\begin{array}{l}\text { Contributed to } \\
\text { all stages of } \\
\text { developing the } \\
\text { guidelines }\end{array}$ \\
\hline $\begin{array}{l}\text { Nazem } \\
\text { Atassi, MD }\end{array}$ & $\begin{array}{l}\text { Massachusetts General } \\
\text { Hospital/Harvard } \\
\text { University }\end{array}$ & $\begin{array}{l}\text { Member } \\
\text { of } \\
\text { section } 6\end{array}$ & $\begin{array}{l}\text { Contributed to } \\
\text { all stages of } \\
\text { developing the } \\
\text { guidelines }\end{array}$ \\
\hline $\begin{array}{l}\text { Kevin } \\
\text { Boylan, MD }\end{array}$ & $\begin{array}{l}\text { Mayo Clinic, } \\
\text { Jacksonville }\end{array}$ & $\begin{array}{l}\text { Member } \\
\text { of } \\
\text { section } 6\end{array}$ & $\begin{array}{l}\text { Contributed to } \\
\text { all stages of } \\
\text { developing the } \\
\text { guidelines }\end{array}$ \\
\hline $\begin{array}{l}\text { Mamede de } \\
\text { Carvalho, } \\
\text { MD }\end{array}$ & $\begin{array}{l}\text { University of Lisbon, } \\
\text { Portugal }\end{array}$ & $\begin{array}{l}\text { Member } \\
\text { of } \\
\text { section } 6\end{array}$ & $\begin{array}{l}\text { Contributed to } \\
\text { all stages of } \\
\text { developing the } \\
\text { guidelines }\end{array}$ \\
\hline $\begin{array}{l}\text { Amanda } \\
\text { Haidet- } \\
\text { Phillips, PhD }\end{array}$ & $\begin{array}{l}\text { Muscular Dystrophy } \\
\text { Association }\end{array}$ & $\begin{array}{l}\text { Member } \\
\text { of } \\
\text { section } 6\end{array}$ & $\begin{array}{l}\text { Contributed to } \\
\text { all stages of } \\
\text { developing the } \\
\text { guidelines }\end{array}$ \\
\hline $\begin{array}{l}\text { Sanjay Kalra, } \\
\text { MD }\end{array}$ & University of Alberta & $\begin{array}{l}\text { Member } \\
\text { of } \\
\text { section } 6\end{array}$ & $\begin{array}{l}\text { Contributed to } \\
\text { all stages of } \\
\text { developing the } \\
\text { guidelines }\end{array}$ \\
\hline $\begin{array}{l}\text { Matthew } \\
\text { Kiernan, } \\
\text { PhD, DSc }\end{array}$ & University of Sydney & $\begin{array}{l}\text { Member } \\
\text { of } \\
\text { section } 6\end{array}$ & $\begin{array}{l}\text { Contributed to } \\
\text { all stages of } \\
\text { developing the } \\
\text { guidelines }\end{array}$ \\
\hline $\begin{array}{l}\text { David } \\
\text { Lacomis, MD }\end{array}$ & University of Pittsburgh & $\begin{array}{l}\text { Member } \\
\text { of } \\
\text { section } 6\end{array}$ & $\begin{array}{l}\text { Contributed to } \\
\text { all stages of } \\
\text { developing the } \\
\text { guidelines }\end{array}$ \\
\hline $\begin{array}{l}\text { Pierre- } \\
\text { Francois } \\
\text { Pradat, MD, } \\
\text { PhD }\end{array}$ & $\begin{array}{l}\text { Pitié-Salpêtrière } \\
\text { Hospital }\end{array}$ & $\begin{array}{l}\text { Member } \\
\text { of } \\
\text { section } 6\end{array}$ & $\begin{array}{l}\text { Contributed to } \\
\text { all stages of } \\
\text { developing the } \\
\text { guidelines }\end{array}$ \\
\hline $\begin{array}{l}\text { Markus } \\
\text { Weber, MD } \\
\text { (co-chair) }\end{array}$ & $\begin{array}{l}\text { St. Gallen Cantonal } \\
\text { Hospital }\end{array}$ & $\begin{array}{l}\text { Member } \\
\text { of } \\
\text { section } 6\end{array}$ & $\begin{array}{l}\text { Contributed to } \\
\text { all stages of } \\
\text { developing the } \\
\text { guidelines }\end{array}$ \\
\hline $\begin{array}{l}\text { Robert } \\
\text { Bowser, PhD }\end{array}$ & $\begin{array}{l}\text { Barrow Neurological } \\
\text { Institute }\end{array}$ & $\begin{array}{l}\text { Member } \\
\text { of } \\
\text { section } 6\end{array}$ & $\begin{array}{l}\text { Contributed to } \\
\text { all stages of } \\
\text { developing the } \\
\text { guidelines }\end{array}$ \\
\hline $\begin{array}{l}\text { Alex } \\
\text { Sherman, } \\
\text { MS, ABD }\end{array}$ & $\begin{array}{l}\text { Massachusetts General } \\
\text { Hospital/Harvard } \\
\text { University }\end{array}$ & $\begin{array}{l}\text { Member } \\
\text { of } \\
\text { section } 6\end{array}$ & $\begin{array}{l}\text { Contributed to } \\
\text { all stages of } \\
\text { developing the } \\
\text { guidelines }\end{array}$ \\
\hline
\end{tabular}

Continued 
Appendix 2 (continued)

\begin{tabular}{|c|c|c|c|}
\hline Name & Location & Role & Contribution \\
\hline $\begin{array}{l}\text { Rubika } \\
\text { Balendra, } \\
\text { MD }\end{array}$ & $\begin{array}{l}\text { University of Central } \\
\text { London }\end{array}$ & $\begin{array}{l}\text { Member } \\
\text { of } \\
\text { section } 7\end{array}$ & $\begin{array}{l}\text { Contributed to } \\
\text { all stages of } \\
\text { developing the } \\
\text { guidelines }\end{array}$ \\
\hline $\begin{array}{l}\text { Christopher } \\
\text { Coffey, PhD }\end{array}$ & University of Iowa & $\begin{array}{l}\text { Member } \\
\text { of } \\
\text { sections } \\
7 \text { and } 9\end{array}$ & $\begin{array}{l}\text { Contributed to } \\
\text { all stages of } \\
\text { developing the } \\
\text { guidelines }\end{array}$ \\
\hline $\begin{array}{l}\text { Dave Ennist, } \\
\text { PhD, MBA }\end{array}$ & $\begin{array}{l}\text { Origent Data Sciences, } \\
\text { Inc. }\end{array}$ & $\begin{array}{l}\text { Member } \\
\text { of } \\
\text { section } 7\end{array}$ & $\begin{array}{l}\text { Contributed to } \\
\text { all stages of } \\
\text { developing the } \\
\text { guidelines }\end{array}$ \\
\hline $\begin{array}{l}\text { Mary Kay } \\
\text { Floeter, MD, } \\
\text { PhD }\end{array}$ & $\begin{array}{l}\text { National Institute of } \\
\text { Neurological Disorders } \\
\text { and Stroke }\end{array}$ & $\begin{array}{l}\text { Member } \\
\text { of } \\
\text { section } 7\end{array}$ & $\begin{array}{l}\text { Contributed to } \\
\text { all stages of } \\
\text { developing the } \\
\text { guidelines }\end{array}$ \\
\hline $\begin{array}{l}\text { Ryuji Kaji, } \\
\text { MD, PhD }\end{array}$ & Tokushima University & $\begin{array}{l}\text { Member } \\
\text { of } \\
\text { section } 7\end{array}$ & $\begin{array}{l}\text { Contributed to } \\
\text { all stages of } \\
\text { developing the } \\
\text { guidelines }\end{array}$ \\
\hline $\begin{array}{l}\text { Yasushi } \\
\text { Kisanuki, MD }\end{array}$ & Ohio State University & $\begin{array}{l}\text { Member } \\
\text { of } \\
\text { section } 7\end{array}$ & $\begin{array}{l}\text { Contributed to } \\
\text { all stages of } \\
\text { developing the } \\
\text { guidelines }\end{array}$ \\
\hline $\begin{array}{l}\text { Shafeeq } \\
\text { Ladha, MD }\end{array}$ & $\begin{array}{l}\text { Barrow Neurological } \\
\text { Institute }\end{array}$ & $\begin{array}{l}\text { Member } \\
\text { of } \\
\text { section } 7\end{array}$ & $\begin{array}{l}\text { Contributed to } \\
\text { all stages of } \\
\text { developing the } \\
\text { guidelines }\end{array}$ \\
\hline $\begin{array}{l}\text { Georgios } \\
\text { Manousakis, } \\
\text { MD }\end{array}$ & $\begin{array}{l}\text { University of } \\
\text { Minnesota }\end{array}$ & $\begin{array}{l}\text { Member } \\
\text { of } \\
\text { section } 7\end{array}$ & $\begin{array}{l}\text { Contributed to } \\
\text { all stages of } \\
\text { developing the } \\
\text { guidelines }\end{array}$ \\
\hline $\begin{array}{l}\text { Michael } \\
\text { McDermott, } \\
\text { PhD }\end{array}$ & University of Rochester & $\begin{array}{l}\text { Member } \\
\text { of } \\
\text { sections } \\
7 \text { and } 9\end{array}$ & $\begin{array}{l}\text { Contributed to } \\
\text { all stages of } \\
\text { developing the } \\
\text { guidelines }\end{array}$ \\
\hline $\begin{array}{l}\text { Robert G. } \\
\text { Miller, MD }\end{array}$ & $\begin{array}{l}\text { California Pacific } \\
\text { Medical Center, Forbes } \\
\text { Norris MDA/ALS } \\
\text { Research Center }\end{array}$ & $\begin{array}{l}\text { Member } \\
\text { of } \\
\text { section } 7\end{array}$ & $\begin{array}{l}\text { Contributed to } \\
\text { all stages of } \\
\text { developing the } \\
\text { guidelines }\end{array}$ \\
\hline $\begin{array}{l}\text { Stephen } \\
\text { Scelsa, MD }\end{array}$ & $\begin{array}{l}\text { Neuromuscular } \\
\text { Division and ALS } \\
\text { Center, Mount Sinai } \\
\text { Beth Israel, and Icahn } \\
\text { School of Medicine at } \\
\text { Mount Sinai }\end{array}$ & $\begin{array}{l}\text { Member } \\
\text { of } \\
\text { section } 7\end{array}$ & $\begin{array}{l}\text { Contributed to } \\
\text { all stages of } \\
\text { developing the } \\
\text { guidelines }\end{array}$ \\
\hline $\begin{array}{l}\text { Lorne } \\
\text { Zinman, MD }\end{array}$ & University of Toronto & $\begin{array}{l}\text { Member } \\
\text { of } \\
\text { section } 7\end{array}$ & $\begin{array}{l}\text { Contributed to } \\
\text { all stages of } \\
\text { developing the } \\
\text { guidelines }\end{array}$ \\
\hline $\begin{array}{l}\text { Merit } \\
\text { Cudkowicz, } \\
\text { MD, MSc }\end{array}$ & $\begin{array}{l}\text { Massachusetts General } \\
\text { Hospital }\end{array}$ & $\begin{array}{l}\text { Member } \\
\text { of } \\
\text { section } 7\end{array}$ & $\begin{array}{l}\text { Contributed to } \\
\text { all stages of } \\
\text { developing the } \\
\text { guidelines }\end{array}$ \\
\hline $\begin{array}{l}\text { Stacy } \\
\text { Rudnicki, MD }\end{array}$ & Cytokinetics & $\begin{array}{l}\text { Member } \\
\text { of } \\
\text { section } 7\end{array}$ & $\begin{array}{l}\text { Contributed to } \\
\text { all stages of } \\
\text { developing the } \\
\text { guidelines }\end{array}$ \\
\hline $\begin{array}{l}\text { Andrew } \\
\text { Wolff, MD }\end{array}$ & Cytokinetics & $\begin{array}{l}\text { Member } \\
\text { of } \\
\text { section } 7\end{array}$ & $\begin{array}{l}\text { Contributed to } \\
\text { all stages of } \\
\text { developing the } \\
\text { guidelines }\end{array}$ \\
\hline
\end{tabular}

Appendix 2 (continued)

\begin{tabular}{|c|c|c|c|}
\hline Name & Location & Role & Contribution \\
\hline $\begin{array}{l}\text { Joseph } \\
\text { Americo } \\
\text { Fernandes, } \\
\text { Jr., MD }\end{array}$ & $\begin{array}{l}\text { University of Nebraska } \\
\text { Medical Center }\end{array}$ & $\begin{array}{l}\text { Member } \\
\text { of } \\
\text { section } 8\end{array}$ & $\begin{array}{l}\text { Contributed to } \\
\text { all stages of } \\
\text { developing the } \\
\text { guidelines }\end{array}$ \\
\hline $\begin{array}{l}\text { Jonathan } \\
\text { Glass, MD }\end{array}$ & Emory University & $\begin{array}{l}\text { Member } \\
\text { of } \\
\text { section } 8\end{array}$ & $\begin{array}{l}\text { Contributed to } \\
\text { all stages of } \\
\text { developing the } \\
\text { guidelines }\end{array}$ \\
\hline $\begin{array}{l}\text { Edward } \\
\text { Kasarskis, } \\
\text { MD, PhD }\end{array}$ & University of Kentucky & $\begin{array}{l}\text { Member } \\
\text { of } \\
\text { section } 8\end{array}$ & $\begin{array}{l}\text { Contributed to } \\
\text { all stages of } \\
\text { developing the } \\
\text { guidelines }\end{array}$ \\
\hline $\begin{array}{l}\text { Donald } \\
\text { Johns, MD }\end{array}$ & Axon Guidance, LLC & $\begin{array}{l}\text { Member } \\
\text { of } \\
\text { section } 8\end{array}$ & $\begin{array}{l}\text { Contributed to } \\
\text { all stages of } \\
\text { developing the } \\
\text { guidelines }\end{array}$ \\
\hline $\begin{array}{l}\text { Katherine } \\
\text { Nicholson, } \\
\text { MD }\end{array}$ & $\begin{array}{l}\text { Massachusetts General } \\
\text { Hospital }\end{array}$ & $\begin{array}{l}\text { Member } \\
\text { of } \\
\text { section } 8\end{array}$ & $\begin{array}{l}\text { Contributed to } \\
\text { all stages of } \\
\text { developing the } \\
\text { guidelines }\end{array}$ \\
\hline $\begin{array}{l}\text { Malcolm } \\
\text { Proudfoot, } \\
\text { MD }\end{array}$ & University of Oxford & $\begin{array}{l}\text { Member } \\
\text { of } \\
\text { section } 8\end{array}$ & $\begin{array}{l}\text { Contributed to } \\
\text { all stages of } \\
\text { developing the } \\
\text { guidelines }\end{array}$ \\
\hline $\begin{array}{l}\text { Steven } \\
\text { Ringel, MD }\end{array}$ & $\begin{array}{l}\text { University of Colorado } \\
\text { at Denver }\end{array}$ & $\begin{array}{l}\text { Member } \\
\text { of } \\
\text { section } 8\end{array}$ & $\begin{array}{l}\text { Contributed to } \\
\text { all stages of } \\
\text { developing the } \\
\text { guidelines }\end{array}$ \\
\hline $\begin{array}{l}\text { David } \\
\text { Schoenfeld, } \\
\text { PhD }\end{array}$ & Harvard University & $\begin{array}{l}\text { Member } \\
\text { of } \\
\text { sections } \\
8 \text { and } 9\end{array}$ & $\begin{array}{l}\text { Contributed to } \\
\text { all stages of } \\
\text { developing the } \\
\text { guidelines }\end{array}$ \\
\hline $\begin{array}{l}\text { David Walk, } \\
\text { MD }\end{array}$ & $\begin{array}{l}\text { University of } \\
\text { Minnesota }\end{array}$ & $\begin{array}{l}\text { Member } \\
\text { of } \\
\text { section } 8\end{array}$ & $\begin{array}{l}\text { Contributed to } \\
\text { all stages of } \\
\text { developing the } \\
\text { guidelines }\end{array}$ \\
\hline $\begin{array}{l}\text { Terry } \\
\text { Heiman- } \\
\text { Patterson, } \\
\text { MD }\end{array}$ & Temple University & $\begin{array}{l}\text { Member } \\
\text { of } \\
\text { section } 8\end{array}$ & $\begin{array}{l}\text { Contributed to } \\
\text { all stages of } \\
\text { developing the } \\
\text { guidelines }\end{array}$ \\
\hline
\end{tabular}

\section{References}

1. Miller RG, Munsat TL, Swash M, Brooks BR. Consensus guidelines for the design and implementation of clinical trials in ALS. World Federation of Neurology Committee on Research. J Neurol Sci 1999;169:2-12.

2. Mitsumoto H, Brooks BR, Silani V. Clinical trials in amyotrophic lateral sclerosis: why so many negative trials and how can trials be improved? Lancet Neurol 2014;13: 1127-1138.

3. Writing Group; Edaravone (MCI-186) ALS Study Group. Safety and efficacy of edaravone in well defined patients with amyotrophic lateral sclerosis: a randomised, double-blind, placebo-controlled trial. Lancet Neurol 2017;16:505-512.

4. de Boer AS, Eggan K. A perspective on stem cell modeling of amyotrophic lateral sclerosis. Cell Cycle 2015;14:3679-3688.

5. Lancaster MA, Knoblich JA. Organogenesis in a dish: modeling development and disease using organoid technologies. Science 2014;345:1247125.

6. van Es MA, Hardiman O, Chio A, et al. Amyotrophic lateral sclerosis. Lancet 2017 390:2084-2098.

7. Ravits J, Appel S, Baloh RH, et al. Deciphering amyotrophic lateral sclerosis: what phenotype, neuropathology and genetics are telling us about pathogenesis. Amyotroph Lateral Scler Frontotemporal Degener 2013;14(suppl 1):5-18.

8. Al-Chalabi A, Hardiman O, Kiernan MC, Chio A, Rix-Brooks B, van den Berg LH. Amyotrophic lateral sclerosis: moving towards a new classification system. Lancet Neurol 2016;15:1182-1194.

9. Westeneng HJ, Debray TPA, Visser AE, et al. Prognosis for patients with amyotrophic lateral sclerosis: development and validation of a personalised prediction model Lancet Neurol 2018;17:423-433. 
10. Balendra R, Jones A, Jivraj N, et al. Use of clinical staging in amyotrophic lateral sclerosis for phase 3 clinical trials. J Neurol Neurosurg Psychiatry 2015;86:45-49.

11. Rutkove SB, Caress JB, Cartwright MS, et al. Electrical impedance myography correlates with standard measures of ALS severity. Muscle Nerve 2014;49: $441-443$.

12. Rowe G, Wright G. Expert opinions in forecasting: the role of the Delphi technique. In: Armstrong JS, editor. Principles of Forecasting International Series in Operations Research \& Management Science. Boston: Springer; 2001.

13. Burberry A, Suzuki N, Wang JY, et al. Loss-of-function mutations in the C9ORF72 mouse ortholog cause fatal autoimmune disease. Sci Transl Med 2016;8:347ra93.

14. Crisp MJ, Beckett J, Coates JR, Miller TM. Canine degenerative myelopathy: biochemical characterization of superoxide dismutase 1 in the first naturally occurring non-human amyotrophic lateral sclerosis model. Exp Neurol 2013;248:1-9.

15. Nagahisa H, Okabe K, Iuchi Y, Fujii J, Miyata H. Characteristics of skeletal muscle fibers of SOD1 knockout mice. Oxid Med Cell Longev 2016;2016:9345970.

16. Perrin S. Preclinical research: make mouse studies work. Nature 2014;507:423-425.

17. Chiò A, Mora G, Calvo A, Mazzini L, Bottacchi E, Mutani R. Epidemiology of ALS in Italy: a 10-year prospective population-based study. Neurology 2009;72:725-731.

18. Huisman MH, de Jong SW, van Doormaal PT, et al. Population based epidemiology of amyotrophic lateral sclerosis using capture-recapture methodology. J Neurol Neurosurg Psychiatry 2011;82:1165-1170.

19. O'Toole O, Traynor BJ, Brennan P, et al. Epidemiology and clinical features of amyotrophic lateral sclerosis in Ireland between 1995 and 2004. J Neurol Neurosurg Psychiatry 2008;79:30-32.

20. Murphy J, Factor-Litvak P, Goetz R, et al. Cognitive-behavioral screening reveals prevalent impairment in a large multicenter ALS cohort. Neurology 2016;86: 813-820.

21. Kaufmann P, Levy G, Thompson JL, et al. The ALSFRSr predicts survival time in an ALS clinic population. Neurology 2005;64:38-43.

22. Messina P, Beghi E. Modeling drop-outs in amyotrophic lateral sclerosis. Contemp Clin Trials 2012;33:218-222.

23. Traynor BJ, Zhang H, Shefner JM, Schoenfeld D, Cudkowicz ME; NEALS Consortium. Functional outcome measures as clinical trial endpoints in ALS. Neurology 2004;63:1933-1935.

24. Berry JD, Miller R, Moore DH, et al. The Combined Assessment of Function and Survival (CAFS): a new endpoint for ALS clinical trials. Amyotroph Lateral Scler Frontotemporal Degener 2013;14:162-168.

25. Cudkowicz ME, van den Berg LH, Shefner JM, et al. Dexpramipexole versus placebo for patients with amyotrophic lateral sclerosis (EMPOWER): a randomised, doubleblind, phase 3 trial. Lancet Neurol 2013;12:1059-1067.

26. Shefner JM, Watson ML, Meng L, Wolff AA; Neals/Cytokinetics STUDY Team. A study to evaluate safety and tolerability of repeated doses of tirasemtiv in patients with amyotrophic lateral sclerosis. Amyotroph Lateral Scler Frontotemporal Degener 2013;14:574-581.

27. Lou JS, Moore D, Gordon PH, Miller R. Correlates of quality of life in ALS: lessons from the minocycline study. Amyotroph Lateral Scler 2010;11:116-121.

28. Simmons Z. Patient-perceived outcomes and quality of life in ALS. Neurotherapeutics 2015;12:394-402.

29. Strong MJ, Grace GM, Freedman M, et al. Consensus criteria for the diagnosis of frontotemporal cognitive and behavioural syndromes in amyotrophic lateral sclerosis. Amyotroph Lateral Scler 2009;10:131-146.
30. Chiò A, Hammond ER, Mora G, Bonito V, Filippini G. Development and evaluation of a clinical staging system for amyotrophic lateral sclerosis. J Neurol Neurosurg Psychiatry 2015;86:38-44.

31. Hillel AD, Miller RM, Yorkston K, McDonald E, Norris FH, Konikow N. Amyotrophic lateral sclerosis severity scale. Neuroepidemiology 1989;8:142-150.

32. Tramacere I, Dalla Bella E, Chiò A, Mora G, Filippini G, Lauria G. The MITOS system predicts long-term survival in amyotrophic lateral sclerosis. J Neurol Neurosurg Psychiatry 2015;86:1180-1185.

33. Bourke SC, Tomlinson M, Williams TL, Bullock RE, Shaw PJ, Gibson GJ. Effects of non-invasive ventilation on survival and quality of life in patients with amyotrophic lateral sclerosis: a randomised controlled trial. Lancet Neurol 2006;5:140-147.

34. Jawaid A, Murthy SB, Wilson AM, et al. A decrease in body mass index is associated with faster progression of motor symptoms and shorter survival in ALS. Amyotroph Lateral Scler 2010;11:542-548.

35. Carrì MT, Grignaschi G, Bendotti C. Targets in ALS: designing multidrug therapies. Trends Pharmacol Sci 2006;27:267-273.

36. Shefner JM. Multi-drug therapy in amyotrophic lateral sclerosis: combinations of multiple, untested drugs should not be used at this time. Muscle Nerve 2004;30: 676-678.

37. de Wit MP, Koelewijn-van Loon MS, Collins S, Abma TA, Kirwan J. "If I wasn't this robust": patients' expectations and experiences at the Outcome Measures in Rheumatology Conference 2010. Patient 2013;6:179-187.

38. Perlmutter J. Advocate involvement in I-SPY 2. Breast Dis A Year B Q 2011;21:21-24.

39. Berry JD, Cudkowicz ME, Shefner JM. Predicting success: optimizing phase II ALS trials for the transition to phase III. Amyotroph Lateral Scler Frontotemporal Degener 2014;15:1-8.

40. Schoenfeld DA, Cudkowicz M. Design of phase II ALS clinical trials. Amyotroph Lateral Scler 2008;9:16-23.

41. Cudkowicz ME, Katz J, Moore DH, et al. Toward more efficient clinical trials for amyotrophic lateral sclerosis. Amyotroph Lateral Scler 2010;11:259-265.

42. Simon NG, Turner MR, Vucic S, et al. Quantifying disease progression in amyotrophic lateral sclerosis. Ann Neurol 2014;76:643-657.

43. Wicks P, Vaughan TE, Massagli MP, Heywood J. Accelerated clinical discovery using self-reported patient data collected online and a patient-matching algorithm. Nat Biotechnol 2011;29:411-414.

44. Howard JF Jr, Utsugisawa K, Benatar M, et al. Safety and efficacy of eculizumab in anti-acetylcholine receptor antibody-positive refractory generalised myasthenia gravis (REGAIN): a phase 3, randomised, double-blind, placebo-controlled, multicentre study. Lancet Neurol 2017;16:976-986.

45. Smith R, Pioro E, Myers K, et al. Enhanced bulbar function in amyotrophic lateral sclerosis: the Nuedexta treatment trial. Neurotherapeutics 2017;14:762-772.

46. Gordon $\mathrm{PH}$, Meininger V. How can we improve clinical trials in amyotrophic lateral sclerosis? Nat Rev Neurol 2011;7:650-654.

47. Ittner LM, Halliday GM, Kril JJ, Götz J, Hodges JR, Kiernan MC. FTD and ALS translating mouse studies into clinical trials. Nat Rev Neurol 2015;11:360-366.

48. Joyce PI, Fratta P, Fisher EM, Acevedo-Arozena A. SOD1 and TDP-43 animal models of amyotrophic lateral sclerosis: recent advances in understanding disease toward the development of clinical treatments. Mamm Genome 2011;22:420-448.

49. Gama Sosa MA, De Gasperi R, Elder GA. Modeling human neurodegenerative diseases in transgenic systems. Hum Genet 2012;131:535-563.

50. Philips T, Rothstein JD. Rodent models of amyotrophic lateral sclerosis. Curr Protoc Pharmacol 2015;69:5-21. 


\section{Neurology}

\section{Revised Airlie House consensus guidelines for design and implementation of ALS clinical trials}

Leonard H. van den Berg, Eric Sorenson, Gary Gronseth, et al.

Neurology 2019;92;e1610-e1623 Published Online before print March 8, 2019

DOI 10.1212/WNL.0000000000007242

\section{This information is current as of March 8, 2019}

\section{Updated Information \&} Services

References

Citations

Subspecialty Collections

Permissions \& Licensing

Reprints including high resolution figures, can be found at: http://n.neurology.org/content/92/14/e1610.full

This article cites 49 articles, 11 of which you can access for free at: http://n.neurology.org/content/92/14/e1610.full\#ref-list-1

This article has been cited by 8 HighWire-hosted articles: http://n.neurology.org/content/92/14/e1610.full\#\#otherarticles

This article, along with others on similar topics, appears in the following collection(s):

\section{All Clinical trials}

http://n.neurology.org/cgi/collection/all_clinical_trials

Amyotrophic lateral sclerosis

http://n.neurology.org/cgi/collection/amyotrophic_lateral_sclerosis_ Clinical trials Methodology/study design

http://n.neurology.org/cgi/collection/clinical_trials_methodology_study _design_

Information about reproducing this article in parts (figures,tables) or in its entirety can be found online at:

http://www.neurology.org/about/about_the_journal\#permissions

Information about ordering reprints can be found online:

http://n.neurology.org/subscribers/advertise

Neurology ${ }^{\circledR}$ is the official journal of the American Academy of Neurology. Published continuously since 1951, it is now a weekly with 48 issues per year. Copyright Copyright @ 2019 The Author(s). Published by Wolters Kluwer Health, Inc. on behalf of the American Academy of Neurology.. All rights reserved. Print ISSN: 0028-3878. Online ISSN: 1526-632X.

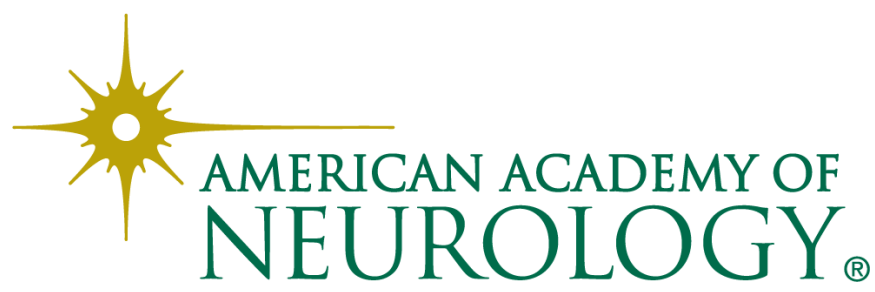

